\title{
Strategi Adaptasi Kata Pinjaman dalam Bahasa Bugis: Koresponden-OO
}

\author{
Muhammad Firdaus Mohd Sah ${ }^{a}$ \\ p111587@siswa.ukm.edu.my \\ Pusat Kajian Bahasa dan Linguistik \\ Fakulti Sains Sosial dan Kemanusiaan \\ Universiti Kebangsaan Malaysia, Malaysia \\ Sharifah Raihan Syed Jaafar ${ }^{b}$ \\ sraihan@ukm.edu.my \\ Pusat Kajian Bahasa dan Linguistik \\ Fakulti Sains Sosial dan Kemanusiaan \\ Universiti Kebangsaan Malaysia, Malaysia
}

\begin{abstract}
ABSTRAK
Sebagai masyarakat minoriti di Malaysia, masyarakat Bugis cenderung menyerap masuk leksikal daripada bahasa lain khususnya daripada masyarakat tempatan di kawasan mereka akibat daripada proses asimilasi yang berlaku. Justeru, kajian ini dilakukan untuk menjawab persoalan: (1) bagaimana strategi adaptasi kata pinjaman yang digunakan dalam penyerapan leksikal asing ke dalam bahasa Bugis, dan (2) bagaimana strategi adaptasi yang berlaku itu dapat dijelaskan menggunakan pendekatan Koresponden-OO yang dibangunkan dalam teori Optimaliti. Data telah dikumpulkan melalui kaedah lapangan dan temu bual dengan menggunakan instrumen borang soal selidik, daftar kata.dan alat rakaman.Kajian lapangan dijalankan di Pontian dan Pasir Gudang, Johor serta di Klang, Selangor. Seramai 144 informan daripada tiga kumpulan umur, iaitu warga muda, warga dewasa dan warga tua terlibat dalam menjawab soal selidik dan daftar kata. Hasil dapatan menunjukkan lapan strategi adaptasi kata pinjaman digunakan dalam bahasa Bugis, iaitu peleburan, pengguguran, penggantian segmen, epentesis, perendahan vokal, penggantian nasal, pembentukan hentian glotis dan geminasi. Analisis Koresponden-OO menunjukkan sifat bahasa Bugis yang tidak bertoleransi dengan nahu asing dengan melarang penyerapan penuh leksikal asing yang dipinjam. Hal ini dapat dilihat pada keperluan mematuhi kekangan kebertandaan *LEKSIKAL SAMA yang mendominasi kekangan-kekangan lain dalam tatatingkat nahu bahasa Bugis. Hasil kajian ini dapat membekalkan input kepada aspek bahasa masyarakat Bugis di Malaysia yang telah dikesampingkan sebelum ini, dan berjaya menunjukkan kemampuan Koresponden-OO dalam menjelaskan isu kata pinjaman tanpa mengingkari konsep penting teori Optimaliti, iaitu Keselarian.
\end{abstract}

Kata Kunci: kata pinjaman; strategi adaptasi; bahasa Bugis; teori Optimaliti; Koresponden$\mathrm{OO}$

a Penulis utama

${ }^{b}$ Penulis koresponden 


\title{
Loan Word Adaptation Strategy in Bugis: Correspondence-OO
}

\begin{abstract}
As a minority community in Malaysia, the Bugis community tends to utilise lexical items from other languages, particularly from local languages as a result of the assimilation process that took place. Thus, this study was conducted to answer the following questions: (1) how are the loanword adaptation strategies used in absorbing foreign language lexical items into the Bugis language, and (2) how can these adaptation strategies be explained by using the Correspondence-OO approach developed in Optimality theory. Data were collected through field methods and interviews using questionnaire, word list and recording. The field studies were conducted in Pontian and Pasir Gudang, Johor as well as in Klang, Selangor. A total of 144 informants from three age groups, namely among the youth, adults and the elderly who were involved in answering the questionnaire and wordlist. The results revealed that eight loanword adaptation strategies were used in Bugis language, namely fusion, deletion, segment substitution, epenthesis, vowel reduction, nasal substitution, glottal stop formation and gemination. The Correspondence-OO analysis showed an element of Bugis language which is intolerant of foreign grammars by prohibiting the full absorption of borrowed foreign lexical items. This can be observed from the needs to comply with a markedness constraint *SAME LEXICAL, that dominates other constraints in the grammar of the Bugis language. The findings of the study can shed input on the language aspects of the Bugis community in Malaysia that were previously excluded. In addition, it has successfully demonstrated the capability of Correspondence-OO in explaining the issue of loanwords without denying the important concept of Optimality theory, namely Parallelism.
\end{abstract}

Keywords: loanword; adaptation strategy; Bugis language; Optimality theory; Correspondence-OO

\section{PENGENALAN}

Pertembungan bahasa dianggap sebagai salah satu fenomena bahasa yang sering berlaku kerana sifat bahasa yang fleksibel. Menurut Brown dan Miller (2013), pertembungan bahasa merujuk kepada situasi penutur daripada bahasa yang berbeza-beza berhubung secara rapat dalam kehidupan seharian yang mengakibatkan proses peminjaman kosa kata, fitur fonetik dan struktur gramatikal bahasa antara satu sama lain dengan bahasa yang dominan akan terus hidup dan sebaliknya bagi bahasa yang tidak dominan. Sebagai contoh, terdapat banyak perkataan daripada bahasa lain yang diserap masuk ke dalam bahasa Inggeris. Antaranya ialah mango, curry, guanxi.

Pada waktu yang sama, fenomena pertembungan bahasa lebih mudah berlaku dalam kelompok masyarakat yang bersifat minoriti. Apabila masyarakat minoriti hidup di kawasan yang mempunyai masyarakat yang lebih dominan dan menuturkan bahasa yang lebih dominan, maka masyarakat minoriti tersebut akan kehilangan autoriti untuk menuturkan bahasa ibunda mereka. Hal yang sama juga berlaku dalam masyarakat minoriti Bugis yang menuturkan bahasa Bugis, mereka kehilangan autoriti untuk menuturkan bahasa Bugis. Masyarakat tersebut merupakan kumpulan masyarakat yang berhijrah dari Sulawesi Selatan, Indonesia ke Tanah Melayu khususnya di negeri Johor. Oleh kerana masyarakat Bugis merupakan golongan minoriti, mereka perlu berasimilasi dengan masyarakat dominan dengan cuba memahami bahasa Melayu bagi kelancaran komunikasi. 


\section{PENYATAAN MASALAH}

Terdapat pelbagai kajian-kajian lepas yang telah berjaya memaparkan perbincangan proses adaptasi kata pinjaman dengan menggunakan teori optimaliti (TO). Antara kajian tersebut ialah, kajian Thamaraselvi Krishnasamy \& Sharifah Raihan Syed Jaafar. (2018) yang membincangkan perubahan fonologi kata pinjaman Tamil yang diserap masuk ke dalam bahasa Melayu. Seterusnya, kajian Aisyah, A., \& Ahmad, Z. (2017) telah memfokuskan kata pinjaman Melayu dalam bahasa Jepun. Kajian yang dilakukan oleh Dedy Suhery et. al. (2019) pula memberi tumpuan kepada kata pinjaman bahasa Inggeris yang terdapat dalam bahasa Pilibhit Hindi-Urdu. Selain itu, kajian Nor Haliza \& Syarifah Raihan(2018) telah dilakukan bagi melihat isu kata pinjaman bahasa Arab dalam dialek Kelantan dengan memfokuskan kepada modifikasi fonologi yang dominan, iaitu proses delikuidasi. Kajian Zibin, A. (2019) pula telah meneliti perubahan kata pinjaman bahasa Inggeris yang berlaku dalam bahasa Arab Jordan. Alahmari, M.(2021) meneliti adaptasi suku kata berat kata pinjaman bahasa Arab dalam bahasa Turki.

Kesemua kajian tersebut telah berjaya membincangkan fenomena adaptasi kata pinjaman dengan memaparkan set kekangan yang telah diingkari bagi penjanaan output. Perbincangan TO juga memperlihatkan proses adaptasi yang berlaku pada tahap input dan output dalam setiap bahasa atau secara mudahnya dengan menggunakan Koresponden InputOutput (Kor-IO)

Tidak dinafikan bahawa kajian-kajian lepas telah berjaya mempamerkan kemampuan TO dalam membincangkan isu kata pinjaman dalam setiap bahasa. Namun begitu, perbincangan yang telah dilakukan pada kajian-kajian lepas hanya membincangkan pada tahap input dan output sahaja di mana perbincangan tersebut hanya memperlihatkan input dan output dari satu sudut bahasa sahaja. Oleh itu, kajian ini mencadangkan penggunaan koresponden output-output (Kor-OO) bagi memperlihatkan isu fenomena adaptasi kata pinjaman dalam bahasa Bugis. Hal ini kerana, Kor-OO mampu memperlihatkan data sesuatu bahasa di luar pemetaan Kor-IO yang sering digunakan oleh pengkaji-pengkaji lepas.

Berdasarkan data, "basek" [basə?] dan "bo" [bõ] merupakan leksikal yang diserap masuk daripada bahasa Inggeris iaitu "bus" [bas] dan "book" [bək]. Jika diperlihatkan data, kedua-dua output tersebut berbeza dengan output bahasa sumber . Jika fenomena ini diperlihatkan secara Kor-IO perkaitan antara dua bahasa ini tidak dapat diperlihatkan kerana akan berlaku derivasi secara berperingkat-peringkat dan akan melanggar konsep keselarian (parallelism) yang merupakan antara lima prinsip asas dalam TO. Berdasarkan McCarthy dan Prince (1994) terdapat lima prinsip asas TO yang perlu dipatuhi dan salah satunya adalah prinsip keselarian (parallelism) yang ditakrifkan bahawa calon-calon terbaik yang telah dijana, dinilai secara menyeluruh, yakni meliputi keseluruhan tatatingkat dan juga kesemua calon. Derivasi secara berperingkat-peringkat tidak wujud. Jika penilaian ke atas data antara dua bahasa ini dilihat secara Kor-IO maka penilaian TO tersebut tidak tepat dan melanggar prinsip asas TO tersebut.

Maka dengan menggunakan Kor-OO yang telah diperkenalkan oleh Benua (1997) fenomena adaptasi kata pinjaman dapat dilihat luar daripada pemetaan Kor-IO tanpa melanggar prinsip asas TO iaitu keselarian (Parallelism). Penggunaan Kor-OO adalah berdasarkan idea bahawa sesetengah perkataan yang terbentuk itu dinilai bukan sahaja berdasarkan kepada inputnya tetapi juga dengan perkataan lain ataupun output lain. Oleh Itu, makalah ini akan membincangkan beberapa isu yang timbul, iaitu (1) bagaimana strategi adaptasi kata pinjaman yang digunakan dalam penyerapan leksikal asing ke dalam bahasa Bugis, dan (2) bagaimana strategi adaptasi yang berlaku itu dapat dijelaskan secara teoretikal menggunakan teori Optimaliti (TO) (Prince dan Smolensky 1993) dengan pendekatan Koresponden-OO (Benua,1997). 


\section{KAJIAN LITERATUR}

Penelitian terhadap masyarakat Bugis telah banyak dilakukan dalam kajian lepas daripada pelbagai aspek seperti sejarah, sosiobudaya, politik, bahasa dan lain-lain lagi. Contohnya, kajian yang dijalankan oleh Makmur et al. (2014), Norhayati (2016), Jasni (2016), Wekke et al. (2019), dan Rahilah Omar et al. (2012) merupakan antara kajian lepas yang telah menyentuh aspek sejarah masyarakat Bugis. Kajian-kajian yang telah dilakukan oleh Rosmiza, \& Sharifah Raihan (2021), Zurina \& Muhammad Abdul (2019), Ridhwan (2019), Mansur et al. (2019), Adijah, at al. (2017), dan Yatim et al. (2020), merupakan kajian yang telah membincangkan masyarakat Bugis di Malaysia dari sudut aspek sosiobudaya. Macknight (2012), Sua (2020), Fitrah \& Afria (2017), Amir (2011), Oktavaniani et al. (2021) telah menyentuh aspek bahasa Bugis dalam kajian mereka seperti sapaan dalam bahasa Bugis, fonetik, dan lain-lain lagi.

Berdasarkan daripada kajian lepas berkaitan masyarakat Bugis khususnya di Malaysia, perbincangan berkenaan komuniti minoriti ini banyak ditinjau dari aspek sejarahnya. Asal usul kedatangan ke Tanah Melayu yang bermula pada abad ke-17 dan awal abad ke-18 di selatan Tanah Melayu, pembukaan penempatan awal masyarakat ini di Johor, Selangor dan Perak hingga ke Barat Siam Thailand telah dibincangkan dengan begitu meluas dalam kajian lepas. Begitu juga kajian dari aspek sosiobudaya masyarakat ini. Amalan tradisi masyarakat Bugis yang masih diamalkan hingga kini. (Rosmiza \& Sharifah Raihan, 2021, Ridhwan, 2019, bin Tanra et al. 2019), agama yang dianutinya (Rosmiza \& Sharifah Raihan, 2021 \& Adijah, at al. 2017), dan budaya masyarakat Bugis (Zurina \& Muhammad Abdul, M, 2019 \& Yatim et al., 2020), antara yang telah dibincangkan.

Namun perbincangan dari sudut bahasa masih lagi kurang mendapat sambutan terutamanya kajian bahasa Bugis di Malaysia. Kajian lepas bahasa Bugis kebanyakannya tertumpu di tanah air mereka, iaitu di Indonesia seperti yang telah dibincangkan oleh Sua (2020), Fitrah, \& Afria,. (2017), Amir (2011), Oktaviani, et al. (2021) dan Jumiati, (2016). Masyarakat Bugis yang ada di Malaysia berbeza dengan masyarakat Bugis di Indonesia. Bugis di Malaysia sudah lama berasimilasi dengan bahasa tempatan (Tanra, \& Amat, 2021). Bahasa Melayu, dan bahasa-bahasa lain yang juga menjadi bahasa pertuturan di Malaysia sudah tentu sedikit sebanyak mempengaruhi bahasa Bugis.

Kajian dari aspek bahasa mempunyai kepentingannya lebih-lebih lagi bahasa masyarakat minoriti. Bugis sebagai salah satu masyarakat minoriti di Malaysia telah menetap dan berasimilasi dengan masyarakat tempatan yang menyebabkan komuniti Bugis di negara ini mula kehilangan kuasa untuk menuturkan bahasa ibunda mereka. Mereka perlu beradaptasi dengan bahasa, budaya dan tradisi tempatan yang berbeza dengan bahasa, budaya dan tradisi ibunda mereka. Dari segi bahasa, kesannya dapat dilihat dalam penggunaan leksikal Melayu yang diserap masuk ke dalam bahasa Bugis, misalnya, [ləmõ] 'limau', [tello] 'telur' dan [aladi] 'keladi'. Menariknya, bukan sahaja leksikal Melayu yang diserap ke dalam bahasa Bugis, malahan leksikal daripada bahasa-bahasa lain juga turut diserap seperti bahasa Inggeris iaitu [talifon] 'telefon', Jerman iaitu [oto] 'auto', Arab iaitu [masigi] 'masjid', dan lain-lain lagi.

\section{METODOLOGI}

Kajian yang dilakukan ini bersifat kualitatif. Kajian kualitatif merupakan terma yang digunakan bagi merujuk kepada metodologi kajian yang kompleks dan berkembang. Data untuk kajian ini telah dikumpulkan melalui beberapa kaedah iaitu kaedah lapangan dan temu bual dengan menggunakan instrumen borang soal selidik, daftar kata dan alat rakaman. Soal selidik dan senarai daftar kata disediakan bertujuan mendapatkan maklumat tentang latar belakang responden dan data kata pinjaman dalam bahasa Bugis. Oleh itu, bagi memastikan maklumat latar belakang dan data kajian diperolehi, soal selidik yang disediakan telah 
dibahagikan kepada dua bahagian, iaitu bahagian A dan bahagian B. Bahagian A merupakan bahagian yang memfokuskan kepada maklumat tentang latar belakang responden.

Manakala pada bahagian B, merupakan senarai daftar kata yang digunakan bagi mendapatkan data berkenaan kata pinjaman dalam bahasa Bugis. Sebanyak 45 daftar kata digunakan dan dikelompokkan kepada lima bahagian, iaitu kata nama, kata kerja, kata adjektif, makanan dan rasa. Bagi kata nama dan kata kerja leksikal yang dipilih lebih tertumpu kepada pelayaran dan perdagangan sebagai contoh, "duit", "cangkul", "kapal", dan bagi kata kerja pula seperti "jual", "menanam" dan lain-lain lagi. Pada waktu yang sama, bagi kelompok kata adjektif, makanan dan rasa kesemua daftar kata yang dipilih adalah berkait rapat dengan barang-barang dan aktiviti sehari-hari masyarakat Bugis. Ini bertujuan untuk memudahkan masyarakat Bugis menterjemahkan daftar kata yang diberikan. Kaedah daftar kata dilakukan dengan cara menemu bual responden menerusi penyebutan setiap daftar kata yang diberikan oleh responden di transkripsikan ke dalam simbol fonetik.

Kewujudan masyarakat Bugis dapat dikesan di beberapa penempatan yang masih kekal hingga sekarang. Mereka tersebar di beberapa buah kampung dalam mukim-mukim di Johor seperti Benut, Sungai Karang, Serkat, Ayer Masin, Ayer Baloi, Sungai Pinggan, Jeram Batu, Sungai Kluang, Minyak Beku, Sungai Punggur, Pengerang, Muar, Gelang Patah dan sekitar Pekan Nenas. Bahkan ada beberapa buah kampung yang majoriti penduduknya adalah masyarakat Bugis. Maka, bagi mendapatkan data primer, beberapa buah kampung telah dilawati semasa kajian lapangan, iaitu Kampung Batu Hampar, Kampung Belokok, Kampung Sungai Kuali, Jelutong Laut, Parit Archong dan Pekan Nenas yang terletak di Pontian, Johor serta di kampung Pasir Putih di Pasir Gudang, Johor. Selain kawasan tersebut, kajian lapangan juga dijalankan di penempatan Bugis di Pandamaran, Klang, Selangor.

Sewaktu kajian lapangan dilakukan, seramai 144 informan telah ditemu bual, iaitu 71 informan dari Pontian, Johor yang terdiri daripada 34 warga tua dan 37 warga dewasa. Bagi Pasir Gudang, Johor pula seramai 34 informan yang terdiri daripada 11 warga tua dan 24 warga dewasa. Manakala di Klang, Selangor seramai 39 informan yang terdiri daripada 10 warga tua dan 29 warga dewasa. Tujuan temu bual dilakukan adalah untuk mendapatkan data-data selain yang disenaraikan di dalam daftar kata yang berkemungkinan merupakan kata pinjaman dalam bahasa Bugis. Kesemua data tersebut dicatat dan dirakam untuk rujukan semula. Informan dipilih berdasarkan dua kumpulan iaitu warga dewasa dan warga tua. Pemilihan informan dilakukan berdasarkan golongan dewasa dan tua kerana menurut Holmes \& Wilson, (2017) selain daripada unsur gender faktor umur juga memberi kesan kepada penuturan seseorang kerana tahap kematangan seseorang mempengaruhi pemilihan leksikal standard berdasarkan umur mereka. Pada awal sesi kajian lapangan, informan telah diberikan penerangan tentang kajian yang dilakukan, maka sesi bersama informan diteruskan dengan temu bual. Sewaktu temu bual, beberapa daftar kata diberikan dalam bentuk potongan ayat Melayu kepada informan untuk dituturkan dalam bahasa Bugis. Pada waktu yang sama, rakaman dilakukan untuk merekod data daripada responden untuk digunakan dalam kajian. Tujuan rakaman tersebut dilakukan adalah untuk penyimpanan dan pada waktu yang sama data tersebut boleh diulang semula bagi mengesan beberapa leksikal yang merupakan kata pinjaman.

\section{TEORI OPTIMALITI DAN TEORI KORESPONDEN}

Sesebuah teori itu sentiasa berkembang dan ditambah baik dari semasa ke semasa. Dalam TO, beberapa pendekatan baharu telah dibangunkan bagi menyelesaikan persamaan fonologi yang berkait dengan bentuk permukaan. Antaranya ialah teori koresponden yang telah diperkenalkan oleh (McCarthy \& Prince, 1995). Teori ini membekalkan rangka dalam menerangkan kekangan kesetiaan. Rangka tersebut mencadangkan bahawa setiap calon yang diterbitkan oleh penjana termasuk representasi output dan hubungan antara input dan output. Menurut McCarthy \& 
Prince (1995) isu asas dalam TO adalah kesetiaan di antara hubungan representasi. Tambahannya lagi, kesetiaan antara bentuk input dan output dapat difahami dengan teori Koresponden. Definisi tentang teori Koresponden adalah seperti berikut:

"Given two strings $S_{1}$ and $S_{2}$, correspondence is the relation $R$ between the elements of $S_{1}$ to those of $S_{2}$. Elements $\alpha \epsilon S_{1}$ and $\beta \epsilon S_{2}$, are referred to as correspondents of one another when $\alpha R \beta$

(McCarthy \& Prince, 1995, p. 262)

$\mathrm{S}_{1}$ adalah input manakala $\mathrm{S}_{2}$ adalah output. Hubungan antara $\mathrm{S}_{1}$ dan $\mathrm{S}_{2}$ dipanggil sebagai hubungan koresponden-IO. Koresponden-IO sering digunakan dalam analisis TO bagi melihat hubungan antara input dan output dalam sesuatu data bahasa. Selain itu, terdapat beberapa lagi hubungan koresponden berdasarkan teori Koresponden seperti yang terdapat dalam Model Penuh. Berikut ditunjukkan hubungan koresponden yang terdapat dalam Model Penuh:

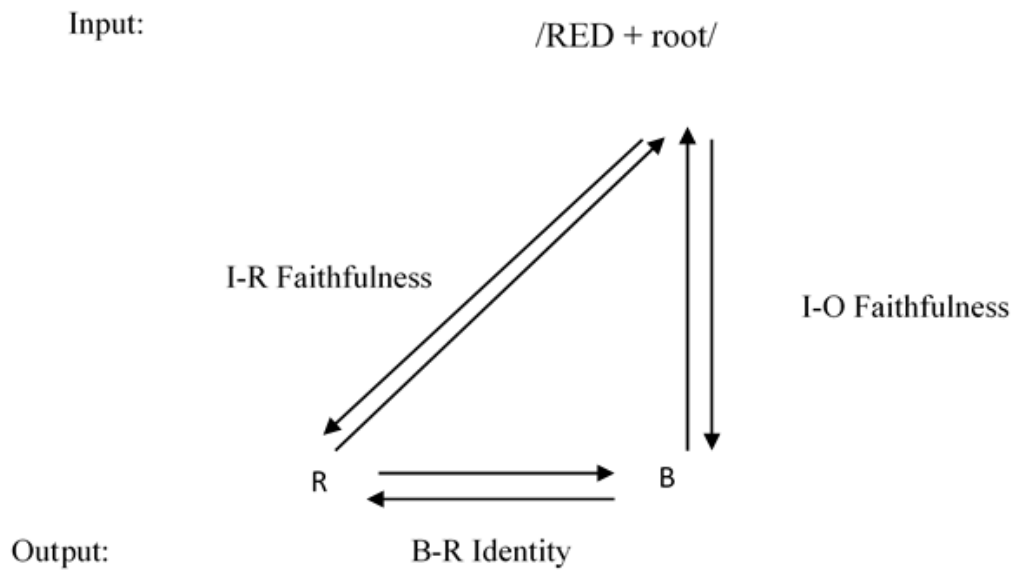

RAJAH 1. Model Penuh

Input:

/RED + root/

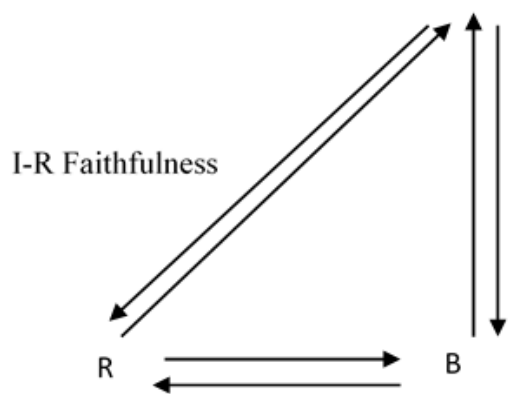

I-O Faithfulness

Output:

B-R Identity

di atas menunjukkan

Model Penuh bagi teori koresponden. Namun, model tersebut berdasarkan fenomena reduplikatif yang berlaku dalam sesebuah bahasa. Berdasarkan rajah dapat dilihat selain daripada koresponden-IO, terdapat juga koresponden input dan base (IB), base dan reduplicant (BR) dan koresponden input dan reduplicunt (IR). Pendekatan Koresponden Output-Output telah diperkenalkan oleh Benua (1997). Kor-OO ini menggunakan sepenuhnya peranan kekangan kebertandaan (McCarthy \& Prince 1995) dan juga berpotensi untuk menyelesaikan 
adaptasi kata pinjaman . Idea asas berkenaan pendekatan ini ialah kata-kata yang berhubung antara input dan output dalam satu bahasa akan dihubungkan secara transderivational atau koresponden output-output (OO) yang merentasi hubungan input-outputnya. Kata-kata yang berhubungan dijanakan secara serentak dalam keadaan selari merentasi hierarki kekangan. Skema Kor-OO yang dicadangkan oleh Benua (1997) adalah seperti berikut:

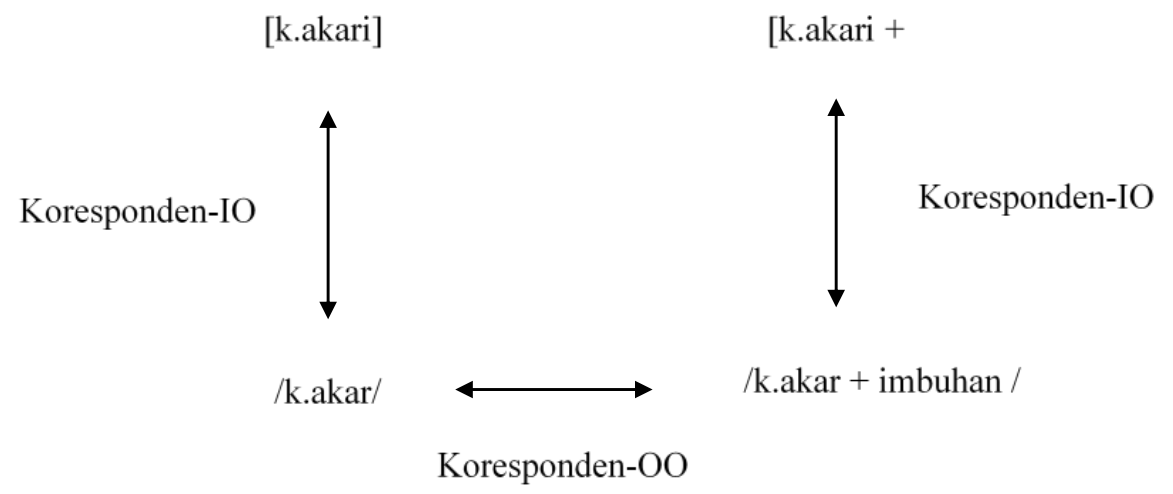

RAJAH 2. Skema Koresponden Output - Output oleh Benua (1997)

Menurut Benua (1997), perkara asas berkenaan koresponden ini ialah perkataan perlu mempunyai identiti fonologi yang sama dan wujud hubungan identiti antara kedua-dua bentuk permukaan. Pendekatan ini melangkaui pemetaan individu input-output dan dinilai berdasarkan bentuk permukaan yang wujud. Kekangan Kor-OO ini akan menghasilkan kesan kitaran tanpa melakukan derivasi kitaran demi mematuhi prinsip keselarian TO. Perkataan yang berhubungan perlu mempunyai identiti fonologi yang sama berdasarkan kekangan KorOO dalam masa yang sama patuh kepada bentuk dalaman berdasarkan kekangan KorespondenIO.

Bagi konteks kata pinjaman pula, hubungan koresponden ini dibincangkan dengan perkaitan kepada adaptasi kata pinjaman. Adaptasi kata pinjaman melibatkan persamaan fonologi antara bentuk permukaan (dalam hal ini, bahasa sumber kepada bahasa peminjam) dan juga tatatingkat kesetiaan yang berlainan yang terlibat dalam koresponden input-output. Adaptasi kata pinjaman berbeza daripada derivasi morfologi di mana bentuk permukaan menunjukkan kesan persamaan fonologi yang melibatkan proses kemasukan bentuk permukaan asing ke dalam sesuatu bahasa natif. Apabila perkataan dipinjam daripada bahasa sumber kepada bahasa pinjaman, maka akan wujud bentuk fonologi yang tidak dibenarkan dalam bahasa peminjaman. Bentuk-bentuk ini akan disesuaikan mengikut beberapa cara. Ada kalanya elemen bukan natif mengalami proses nativisasi sepenuhnya di mana ingkaran fonotaktik bahasa peminjam disingkirkan dan pembaikan dilakukan agar bentuk tersebut sesuai dengan nahu dalaman bahasa peminjam. Berdasarkan penyesuaian ini, kekangan kebertandaan ditatatingkatkan lebih tinggi berbanding kekangan kesetiaan

Senario adaptasi kata pinjaman ini memerlukan suatu mekanisme yang melangkaui asas fonologi bahasa peminjam di mana proses nativasi dan pengekalan elemen bukan natif telah dianalisis sebagai kesan kekangan persamaan (similarity constraints) yang mengaitkan kata pinjaman dengan bentuk bahasa sumbernya. Oleh itu, penggunaan Kor-OO adalah berdasarkan idea bahawa sesetengah perkataan yang terbentuk itu dinilai bukan sahaja berdasarkan kepada inputnya tetapi juga dengan perkataan lain ataupun output lain 


\section{HASIL KAJIAN DAN PERBINCANGAN}

Hasil daripada kajian lapangan, sebanyak lapan proses fonologi yang dapat dikesan dalam penyerapan kata pinjaman bahasa Bugis. Berikut merupakan perbincangan lapan proses fonologi tersebut.

\section{PELEBURAN}

Proses fonologi yang pertama dapat dikesan dalam penyerapan kata pinjaman bahasa Bugis ialah peleburan. Berdasarkan data pada JADUAL 1 dalam konteks kata pinjaman bahasa Bugis, peleburan berlaku apabila terdapat deretan vokal pada posisi onset atau koda dalam leksikal. Berdasarkan data, proses peleburan berlaku apabila terdapat deretan vokal hadir pada posisi onset atau koda. Pada waktu yang sama, terdapat juga satu data yang berlaku peleburan apabila segmen vokal /u/ bergandingan dengan segmen konsonan /r/. Berikut merupakan data:

JADUAL 1. Proses peleburan dalam kata pinjaman dalam bahasa Bugis

\begin{tabular}{ccccc}
\hline Bahasa Sumber & $\begin{array}{c}\text { Representasi } \\
\text { Fonetik }\end{array}$ & Bahasa Bugis & $\begin{array}{c}\text { Representasi } \\
\text { Fonetik }\end{array}$ & Etimologi kata \\
\hline auto & {$[$ aõto: } & oto & {$[$ oto] } & Jerman \\
limau & {$[$ limãw] } & lemo & {$[$ ləmõ] } & Melayu \\
telur & {$[$ təlo(r)] } & tello & {$[$ tello] } & Melayu \\
\hline
\end{tabular}

Berdasarkan JADUAL 1 leksikal /aṽto/ merupakan leksikal yang dipinjam daripada bahasa German. Antara sebab penyerapan bahasa Jerman ke dalam bahasa Bugis boleh berlaku adalah kerana faktor penjajahan dan pendidikan. Menurut Hasmawati (2014) pembelajaran bahasa Jerman telah diterapkan dalam pendidikan sekolah di Indonesia sejak zaman penjajahan Belanda lagi. Tambahan lagi, walaupun penjajahan Belanda sudah berakhir pembelajaran bahasa Jerman tersebut masih diteruskan di beberapa buah sekolah.

Apabila /avoto/ diserap ke dalam bahasa Bugis, deretan vokal /au/ pada posisi awal kata telah dileburkan kepada [o]. Hal ini kerana, leksikal tersebut mempunyai deretan vokal dalam leksikal tersebut yang membuatkan leksikal tersebut tidak diserap masuk sepenuhnya dalam bahasa Bugis.

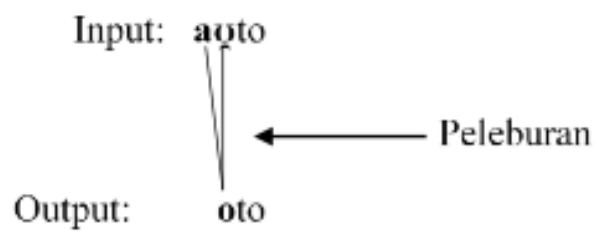

RAJAH 3. Perubahan struktur akibat proses peleburan

RAJAH 3 menunjukkan proses peleburan yang berlaku pada leksikal [oto] di suku kata pertama, segmen /av/ dileburkan menjadi segmen [o]. Proses tersebut membuatkan output [oto] telah mengingkari kekangan UNIFORMITI. UNIFORMITI merupakan salah satu kekangan daripada keluarga kekangan kesetiaan yang tidak membenarkan peleburan berlaku. Oleh sebab proses peleburan berlaku daripada bahasa Jerman yang diserap ke dalam bahasa Bugis, maka hubungan koresponden yang terlibat adalah antara output-output (OO). 
Penilaian Kor-OO ini akan dilakukan antara output bahasa Jerman dan output bahasa Bugis. Penilaian yang berlaku, sama seperti yang berlaku pada tahap IO iaitu kekangan kebertandaan dan kesetiaan akan menilai, namun idea Kor-OO ini adalah memperlihat hubungan antara dua output maka kekangan kesetiaan akan berubah menjadi OO, seperti kekangan yang telah diketengahkan iaitu UNIFORM-OO.Selain daripada kekangan UNIFORM-OO, calon [oto] juga telah mengingkari kekangan IDENTICAL (features). Kekangan tersebut merupakan kekangan yang tidak membenarkan sebarang perubahan fitur yang berlaku. Sama seperti kekangan UNIFORM-OO, kekangan IDENT [F]. Ini juga merupakan kekangan di bawah keluarga kesetiaan. Maka kekangan IDENT[F] akan berubah menjadi OO ekoran perubahan fitur yang berlaku bukan pada penilaian antara input dan output, sebaliknya penilaian tersebut berlaku pada tahap output bahasa Jerman dan bahasa Bugis.

Seterusnya, calon yang dijana dalam analisis ini ialah [aơto:]. Disebabkan [oto] merupakan kata pinjaman yang telah diserap masuk daripada bahasa Jerman, iaitu / aơto;/, calon tersebut juga relevan untuk dijana sebagai salah satu calon. Oleh sebab, berlakunya proses penyesuaian dalam penyerapan kata pinjaman Bugis, calon tersebut tidak diterbitkan sebagai output, namun apakah kekangan yang menyebabkan calon tersebut tidak dapat diterbitkan? Berdasarkan penjanaan calon tersebut, tiga kekangan yang telah diingkari iaitu kekangan *LEKSIKAL SAMA, *VP dan DEP-OO.

Kekangan *LEKSIKAL SAMA merupakan kekangan yang tidak membenarkan dua leksikal yang sama wujud dalam leksikon. Disebabkan calon [aṽto:] merupakan input dalam bahasa Bugis dan pada waktu yang sama merupakan output yang dijana dalam bahasa Jerman iaitu di bawah leksikon yang sama, calon [avto:] telah melanggar kekangan *LEKSIKAL SAMA. Pada waktu yang sama calon tersebut juga telah mengingkari kekangan *VP iaitu kekangan yang tidak membenarkan kewujudan vokal panjang. Pada posisi suku kata terakhir calon [aṽto:] terdapat pemanjangan vokal /o/ yang berlaku. Hal menyebabkan calon tersebut telah mengingkari kekangan *VP. Oleh kerana berlaku kepanjangan vokal, maka calon tersebut turut mengingkari kekangan DEP-OO.

1) $* V P$

Tiada vokal Panjang

2) ONSET

Suku kata haruslah mempunyai onset

3) MAKS-OO

Pengguguran segmen tidak dibenarkan.

UNIFORM-OO

Peleburan tidak dibenarkan

4) *LEKSIKAL SAMA

Dua leksikal yang sama wujud dalam leksikon tidak dibenarkan

\section{5) DEP-OO}

Segmen yang wujud dalam bentuk morfologinya perlu mempunyai koresponden dengan bentuk derivasinya.

\section{6) IDENT[F]-OO}

Tiada perubahan fitur yang berlaku 


\section{1. /avoto: $\longrightarrow[$ oto]}

Tablo kekangan: *LEKSIKALSAMA $>>*$ VP $>>$ ONSET $>>$ DEP-OO $>>$ IDENT[F]-OO $>>$ MAKSOO $>>$ UNIFORM-OO

\begin{tabular}{|c|c|c|c|c|c|c|c|}
\hline /avoto:/ & 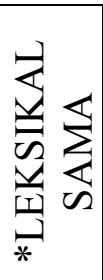 & $\sum_{*}^{p}$ & 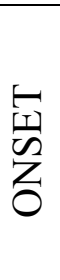 & 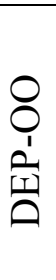 & 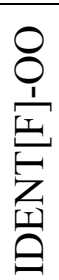 & \begin{tabular}{l}
0 \\
0 \\
1 \\
\\
\multirow{2}{\Delta}{} \\
$\Sigma$
\end{tabular} & 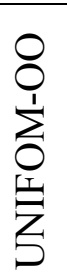 \\
\hline a. oto & & & $*$ & & * & & $* !$ \\
\hline b.avoto: & $* !$ & $*$ & $*$ & * & & & \\
\hline c.ato & & & $*$ & & * & $* !$ & \\
\hline
\end{tabular}

Berdasarkan tablo, dengan mengaplikasi set kekangan dan hierarki kekangan tersebut, calon (a) telah menjadi calon optimal. Kesemua calon telah mengingkari kekangan ONSET yang berada pada tatatingkat ketiga di dalam tablo. Namun, calon (b) telah terkeluar sebagai calon optimal kerana mengingkari kekangan *LEKSIKAL SAMA. Manakala (c) telah terkeluar kerana telah mengingkari tiga kekangan berat iaitu kekangan ONSET, IDENT[F]OO dan MAKS-OO yang berada pada tempat ketiga, keempat dan kelima. Calon (a) juga telah mengingkari kekangan IDENT-OO namun disebabkan kekangan UNIFORM-OO berada tatatingkat paling rendah maka calon (a) telah menjadi calon yang paling optimal. Justeru, set kekangan ketika ini adalah *LEKSIKAL SAMA $>>$ *VP $>>$ DEP-OO $>>$ ONSET $>>$ IDENT[F]-OO $>>$ MAKS-OO $>>$ UNIFORM-OO

\section{PENGGUGURAN}

Seterusnya, proses fonologi yang dapat dikesan dalam penyerapan kata pinjaman bahasa Bugis ialah pengguguran. Pengguguran merupakan fenomena fonologi yang melibatkan penghilangan atau membuang segmen vokal atau konsonan dalam satu leksikal. Proses pengguguran merupakan proses yang sering muncul dalam proses penyerapan kata pinjaman. Seperti yang dinyatakan oleh Guo (1999), terdapat tiga proses fonologi yang sering hadir dalam memperbaiki penyerapan kata pinjaman iaitu pengguguran, penyisipan dan penggantian. Dalam konteks kata pinjaman bahasa Bugis, salah satu daripada proses fonologi ini berlaku, iaitu proses pengguguran segmen. Proses pengguguran segmen berlaku apabila leksikal yang dipinjam itu tidak wujud dalam bahasa Bugis. Berikut adalah contoh data:

JADUAL 2. Data kata pinjaman bahasa Bugis bagi proses pengguguran

\begin{tabular}{ccccc}
\hline Bahasa Sumber & $\begin{array}{c}\text { Representasi } \\
\text { Fonetik }\end{array}$ & Bahasa Bugis & $\begin{array}{c}\text { Representasi } \\
\text { Fonetik }\end{array}$ & Etimologi \\
\hline book & {$[$ brk :] } & bo & {$[$ bõ] } & Inggeris \\
angkat & {$[$ ajkat] } & akak & [aka?] & Melayu \\
mertua & {$[$ mə̃rtua $]$} & matua & {$[$ mãtua } & Melayu \\
rebah & {$[$ rəbah] } & rebba & {$[$ rəbba] } & Melayu \\
keladi & {$[$ kəladi] } & aladi & [aladi] & Melayu \\
langit & {$[$ lajĩt] } & langi & {$[$ lajĩ] } & Melayu \\
\hline
\end{tabular}




\section{Berdasarkan}

JADUAL 2 pengguguran yang berlaku menyebabkan output [bõ] telah mengingkari kekangan MAKS-OO. Sama seperti penerangan pada proses peleburan, oleh kerana proses pengguguran berlaku pada peringkat output bahasa Bugis maka koresponden yang menilai calon tersebut adalah kor-OO. Pada waktu yang sama, apabila pengguguran berlaku, fitur bagi output bahasa sumber dan bahasa Bugis telah berubah, maka calon output bahasa Bugis [b̃̃] juga telah mengingkari kekangan IDENT[F]-OO. Selain daripada calon bahasa Bugis, calon yang relevan dalam penilaian ini adalah [buk] iaitu output bahasa sumber tersebut. Oleh kerana, etimologi leksikal tersebut merupakan dari bahasa Inggeris maka calon [buk] juga sesuai untuk dijana. Hal ini kerana, penilaian TO ini akan memperlihatkan kekangan yang menghalang calon tersebut untuk menjadi calon optimal dalam penjanaan output kata pinjaman bahasa Bugis. Berdasarkan set kekangan sedia ada, calon [buk] telah mengingkari kekangan *LEKSIKAL SAMA. Sama seperti pada proses peleburan, calon yang sama dengan input bahasa sumber telah mengingkari kekangan *LEKSIKAL SAMA.

Seterusnya, calon yang dijana dalam penilaian ini adalah [bo:?]. Calon tersebut dianggap sebagai calon yang relevan kerana, fenomena vokal panjang dalam bahasa Inggeris. Menurut Roach (2000), dalam bahasa Inggeris juga terdapat vokal yang dikenali sebagai vokal panjang. Maka calon [bo:?] dijana bagi melihat sama ada pengaruh kepanjangan vokal dalam bahasa Inggeris turut diserap masuk ke dalam bahasa Bugis. Namun berdasarkan set kekangan sedia ada, calon tersebut telah mengingkari kekangan *VP, DEP-OO, dan IDENT[F]-OO.

Kekangan TIADA KODA juga diutarakan dalam penilaian ini. Kekangan TIADA KODA merupakan kekangan di bawah keluarga kekangan kebertandaan. Oleh kerana idea koresponden-OO ini menggunakan sepenuhnya kekangan kebertandaan maka tidak ada sebarang perubahan yang berlaku pada kekangan tersebut. Berdasarkan penjanaan calon terdapat kewujudan koda pada peringkat input bahasa sumber, maka kekangan TIADA KODA telah diingkari. Pada waktu yang sama, calon [buk] dan [bo:?] juga telah mengingkari kekangan tersebut.

\section{8) TIADA KODA $\rightarrow$}

Sesuatu suku kata tidak boleh mempunyai koda
1. /bơk/
[ bĩ ]

Tablo kekangan: *LEKSIKALSAMA $>>* \mathrm{VP}>>$ DEP-OO $>>$ TIADAKODA $>>$ IDENT[F]$\mathrm{OO}>>$ MAKS-OO $>>$ UNIFORM-OO $>>$ ONSET

\begin{tabular}{|c|c|c|c|c|c|c|c|c|}
\hline /bơk/ & 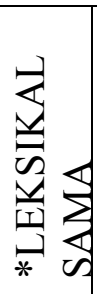 & $\sum_{*}^{\infty}$ & $\begin{array}{l}0 \\
0 \\
\frac{1}{0} \\
\frac{1}{0}\end{array}$ & 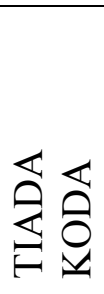 & 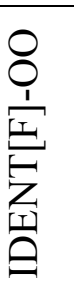 & $\begin{array}{l}0 \\
0 \\
1 \\
21 \\
11 \\
\vdots \\
\Sigma\end{array}$ & 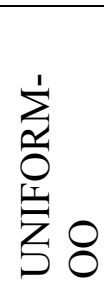 & 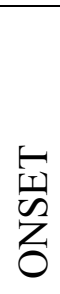 \\
\hline$\sigma^{\circ}$ a. b̃ & & & & & $* !$ & $*$ & & \\
\hline b. bo:? & & $* !$ & * & $*$ & $*$ & & & \\
\hline c. buk & $* !$ & & & $*$ & & & & \\
\hline
\end{tabular}

Berdasarkan penilaian tablo di atas, calon (a) telah berjaya menjadi calon optimal. Calon (b) telah disingkirkan sebagai calon paling optimal kerana calon (b) telah mengingkari kekangan *VP yang berada pada tatatingkat kedua dalam tablo. Seterusnya, walaupun calon (c) merupakan jenis kata pinjaman penyerapan penuh, namun calon ini tidak berjaya muncul 
sebagai calon optimal kerana telah mengingkari kekangan yang paling berat dalam tatatingkat kekangan iaitu kekangan *LEKSIKAL SAMA. Maka set kekangan pada ketika ini adalah *LEKSIKALSAMA $>>$ *VP $>>$ DEP-OO $>>$ TIADAKODA $>>$ IDENT[F]-OO $>>$ MAKSOO $>>$ UNIFORM-OO $>>$ ONSET

\section{PENGGANTIAN SEGMEN}

Proses penggantian segmen berlaku apabila satu segmen dalam leksikal digantikan dengan segmen yang lain. Dalam penyerapan kata pinjaman bahasa Bugis berlakunya proses penggantian pada kedua-dua posisi iaitu onset dan koda. Hal ini disebabkan oleh kecenderungan yang biasa bagi sesuatu bahasa untuk mengekalkan bunyi daripada digugurkan.

Bagi memastikan penyerapan kata pinjaman daripada bahasa sumber dapat diterima ke dalam bahasa Bugis, sesuatu segmen akan digantikan dengan fonem yang terdapat dalam bahasa peminjam. Pada waktu yang sama, semasa proses peminjaman, bunyi input yang terdapat dalam bahasa sumber akan dipetakan kepada bunyi yang hampir sama dengan bahasa penerima. Hal ini kerana struktur fonologi kata pinjaman yang tidak sesuai dengan sistem fonologi bahasa peminjam perlu diadaptasikan sistem fonologi yang sesuai, dan corak adaptasi yang konsisten dapat diperjelaskan dengan mengandaikan kedudukan tertentu kekangan fonologi. Berikut merupakan data yang diperolehi:

JADUAL 3. Data kata pinjaman bahasa Bugis bagi proses penggantian segmen

\begin{tabular}{ccccc}
\hline Bahasa Sumber & $\begin{array}{c}\text { Representasi } \\
\text { Fonetik }\end{array}$ & Bahasa Bugis & $\begin{array}{c}\text { Representasi } \\
\text { Fonetik }\end{array}$ & Etimologi \\
\hline honey & {$[$ h^nĩ:] } & wani & [wani] & Inggeris \\
serai & {$[$ səraj] } & sereh & [səreh] & Melayu \\
sentul & {$[$ səntul] } & settung & [səttup] & Melayu \\
sudu & {$[$ sudu] } & suruk & {$[$ suru?] } & Melayu \\
laki & {$[$ laki] } & lakai & {$[$ lakaj] } & Melayu \\
senduk & {$[$ səndu?] } & sanderuk & [sandəru?] & Melayu \\
mertua & {$[$ mə̃rtua] } & matua & [mãtua] & Melayu \\
keladi & {$[$ kəladi] } & aladi & [aladi] & Melayu \\
besi & {$[$ bəsi] } & bassi & [bassi] & Melayu \\
gula & {$[$ gula] } & golla & [golla] & Melayu \\
\hline
\end{tabular}

Berdasarkan

JADUAL 3 konsonan /h/, /j/, /1/, /d/ dan vokal /i/, /ə/, dan /u/ dalam penyerapan kata pinjaman bahasa Bugis mengalami proses penggantian. Situasi penggantian ini juga dinyatakan sebagai nativisasi. Berdasarkan Trask (2000), sesuatu perkataan yang dipinjam akan mengalami nativisasi melalui penggantian segmen asing dengan segmen natif yang terdapat dalam bahasa peminjam. Hal ini akan menyebabkan perkataan yang dipinjam itu sukar dibezakan daripada bentuk natif. Namun, kenyataan tersebut bercanggah dengan kajian yang dijalankan oleh Macknight (2012). Berdasarkan Macknight (2012), konsonan /h/ wujud dalam bahasa Bugis. Ini bermakna proses penggantian bagi konsonan $/ \mathrm{h} /$ bukan disebabkan konsonan tersebut merupakan konsonan asing. Oleh itu, apakah yang menyebabkan berlakunya penggantian tersebut? Herati (2013) menyatakan bahasa Bugis mempunyai gejala fonologi yang khas yang melibatkan konsonan dan vokal. Gejala atau proses fonologi yang khas tersebut ialah koresponden dan variasi penyebutan dalam bahasa Bugis. Koresponden dan variasi bunyi tersebut terjadi disebabkan oleh berubahnya penekanan pada titik artikulasi iaitu perubahan tersebut merupakan istilah kepada variasi bebas.

Variasi bebas merupakan fenomena penyebutan leksikal yang mempunyai lebih dari satu bentuk kata, untuk kata-kata tertentu. Sebagai contoh, konsonan /w/ merupakan konsonan 
yang berkoresponden dengan konsonan $/ \mathrm{h} /$ dalam bahasa Bugis. Ini membuatkan penyerapan leksikal /hani/ telah disebut sebagai [wãnĩ] kerana konsonan /w/ merupakan konsonan yang mempunyai penyebutan variasi bebas. Namun, Herati (2013) menyatakan pada kata pinjaman yang sudah mempunyai konsonan $/ \mathrm{w} /$, konsonan tersebut tidak akan berubah. Oleh itu, kewujudan proses penggantian tersebut bukan disebabkan kewujudan konsonan asing, tetapi kerana terdapatnya ciri khas dalam bahasa Bugis iaitu variasi bebas yang menjadi punca kepada penggantian tersebut.

Seterusnya, calon yang dijana dalam penilaian ini adalah [a:nĩ]. Calon tersebut telah dijana kerana, sama seperti sebelum ini dalam proses pengguguran, oleh kerana leksikal /hani/ merupakan kata pinjaman daripada bahasa Inggeris, maka munasabah untuk dipertimbangkan jika pengaruh kepanjangan vokal turut diserap masuk ke dalam bahasa Bugis. Namun begitu, berdasarkan set kekangan sedia ada, calon tersebut telah mengingkari lima kekangan iaitu *VP , ONSET, IDENT-OO, DEP-OO dan MAKS-OO. Calon terakhir yang dijana dalam penilaian ini adalah /hani/. Calon tersebut turut layak untuk dinilai kerana ianya merupakan input kepada penyerapan kata pinjaman dalam bahasa Bugis. Namun, sama seperti pada proses yang sebelum ini, apabila input penyerapan kata pinjaman dijadikan sebagai salah satu calon, calon tersebut telah mengingkari kekangan *LEKSIKAL SAMA.

\section{1. $/ \mathrm{h} \Lambda$ ĩ $/ \longrightarrow[$ wanĩ $]$}

Tablo kekangan: *LEKSIKAL SAMA $>>$ *VP $>>$ DEP-OO $>>$ ONSET $>>$ IDENT[F]-OO $>>$ MAKS-OO $>>$ UNIFORM-OO $>>$ TIADADA KODA

\begin{tabular}{|c|c|c|c|c|c|c|c|c|}
\hline 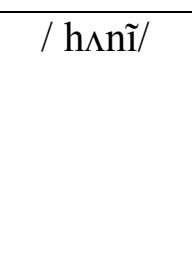 & 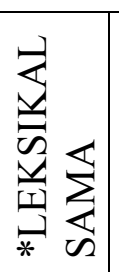 & $\underset{*}{\stackrel{P}{*}}$ & $\begin{array}{l}0 \\
0 \\
0^{\prime} \\
\text { ب⿱ }\end{array}$ & 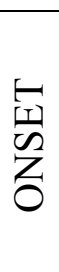 & 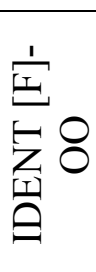 & $\begin{array}{l}0 \\
0 \\
1 \\
2 \\
\vdots 1 \\
\Sigma\end{array}$ & 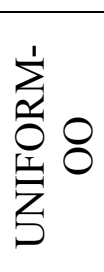 & 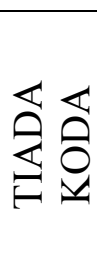 \\
\hline a. wanĩ & & & & & $* !$ & & & \\
\hline b. a:nĩ & & $* !$ & $*$ & $*$ & $*$ & $*$ & & \\
\hline c. hanĩ & $* !$ & & & & & & & \\
\hline
\end{tabular}

Berdasarkan tablo di atas, calon (a) telah berjaya menjadi calon paling optimal. Calon $\mathrm{b}$ telah tersingkir dari menjadi calon optimal kerana telah mengingkari kekangan yang paling banyak dan tewas pada kekangan kedua tertinggi berdasarkan tablo. Manakala calon (c) pula telah tewas dalam penilaian ini kerana calon (c) telah mengingkari kekangan yang paling berat di dalam tablo. Maka set kekangan ketika ini adalah LEKSIKAL SAMA $>>*$ VP $>>$ DEPOO $>>$ ONSET $>>$ IDENT[F]-OO $>>$ MAKS-OO $>>$ UNIFORM-OO $>>$ TIADADA KODA.

\section{EPENTENSIS/ PENYISIPAN}

Proses seterusnya ialah epentesis atau penyisipan. Proses tersebut turut berlaku dalam penyerapan kata pinjaman bahasa Bugis. Penyisipan merupakan proses fonologi yang melibatkan penambahan sesuatu segmen di peringkat output. Berikut merupakan data:

JADUAL 4. Data kata pinjaman bahasa Bugis bagi proses penyisipan

\begin{tabular}{lcccc}
\hline Bahasa Sumber & $\begin{array}{c}\text { Representasi } \\
\text { Fonetik }\end{array}$ & Bahasa Bugis & $\begin{array}{c}\text { Representasi } \\
\text { Fonetik }\end{array}$ & Etimologi \\
\hline
\end{tabular}




\begin{tabular}{|c|c|c|c|c|}
\hline masjid & [mãs.ḑid] & masigi & [mãsigi] & Arab \\
\hline kappal & [kappal] & kappala & [kappala] & Tamil \\
\hline sadal & [sã.dal] & sandala & [sandala] & Perancis Lama \\
\hline garfo & [garfo] & gadeppuh & [gadəppuh] & Belanda \\
\hline bas & [bas] & basek & [base?] & English \\
\hline bicycle & [baisıklt] & basikarak & [basikara?] & Perancis \\
\hline changkir & [tankir] & changkiri & [yaykiri] & Melayu \\
\hline baldi & [baldi] & beladi & [bəladi] & Melayu \\
\hline tidur & [tido] & tindro & [tindro] & Melayu \\
\hline arnab & [arnãb] & arnabek & [arnãbe?] & Arab \\
\hline manggis & [mangis] & manggisik & [maygisi?] & Melayu \\
\hline anggur & [aygur] & anggorok & [aygoro?] & Parsi \\
\hline kipas & [kipas] & kifasak & [kifasa?] & Melayu \\
\hline sabar & [sabar] & sabbarak & [sabbara?] & Arab \\
\hline laki & [laki] & lakai & [lakaj] & Melayu \\
\hline lupa & [lupa] & lupai & [lupaj] & Melayu \\
\hline
\end{tabular}

Berdasarkan JADUAL 4 proses penyisipan melibatkan penyisipan vokal dan konsonan. Antara vokal yang telah disisipkan ialah /i/, /a/, /ə/, /e/, dan /o/ manakala segmen konsonan yang diserap masuk adalah $/ \mathrm{d} / \mathrm{dan} / \mathrm{n} /$. Segmen vokal merupakan segmen yang paling kerap disisipkan. Kesemua vokal yang disisipkan merupakan vokal tinggi iaitu /i/, vokal separuh tinggi /e/, /o/, /o/ dan vokal rendah iaitu /a/. Kewujudan proses penyisipan vokal ini dapat dilihat apabila leksikal yang diserap masuk mempunyai segmen konsonan yang menduduki pada posisi koda. Lalu, vokal yang disisipkan perlu mempunyai tahap ketinggian yang sama. Sebagai contoh, leksikal [kappala] merupakan leksikal yang berasal dari perkataan /kappal/ iaitu daripada bahasa Sanskrit. Oleh sebab terdapat konsonan yang menduduki pada posisi koda vokal [a] telah disisipkan iaitu vokal yang mempunyai tahap ketinggian yang sama dengan vokal yang hadir sebelumnya. Oleh itu, dapat dilihat bahawa proses penyisipan vokal dalam penyerapan kata pinjaman dalam bahasa Bugis ini tidak membenarkan penyisipan vokal yang lebih tinggi atau harus sama dengan vokal yang hadir pada posisi sebelumnya.

Bagi konsonan, segmen yang disisipkan haruslah berhomorganik dengan konsonan yang hadir sebelum. Konsonan homorganik merupakan konsonan yang diklasifikasikan sebagai konsonan yang mempunyai titik artikulatori yang sama. Sebagai contoh, kata pinjaman [tindro] merupakan kata pinjaman yang telah mengalami penyisipan konsonan [n]. Konsonan [n] merupakan konsonan yang berhomorganik dengan konsonan $[\mathrm{t}]$ yang sama titik artikulasi iaitu aveolar. Namun, berlaku juga penyisipan yang tidak berhomorganik dalam proses penyisipan segmen konsonan ini. Sebagai contoh, leksikal [gadəppuh] telah disisipkan konsonan [d] yang merupakan konsonan alveolar. Konsonan yang disisipkan tersebut tidak berhomorganik dengan konsonan yang hadir sebelumnya iaitu /g/ iaitu konsonan velar dan konsonan selepasnya iaitu /p/ yang merupakan konsonan bilabial. Namun persamaan bagi ketiga-tiga konsonan tersebut adalah cara penyebutan atau sekatan udara sewaktu penyebutan konsonan tersebut iaitu konsonan letupan.

Vokal /i/ telah ditambah pada posisi akhir kata. Output yang dijana oleh penutur dijadikan sebagai salah satu calon dalam penilaian TO ini. Berdasarkan set kekangan yang

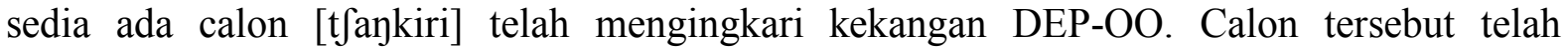

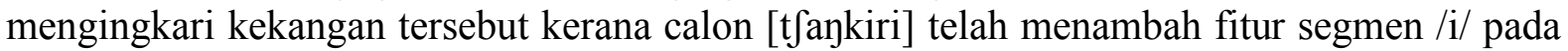
posisi akhir, oleh kerana kekangan DEP-OO tidak membenarkan sebarang penyisipan berlaku maka calon tersebut telah mengingkari DEP-OO.

Seterusnya, calon yang dijana dalam penilaian ini adalah output bahasa sumber [t $\mathrm{faykir}$. Berdasarkan set kekangan sedia ada calon [t $\mathrm{t}$ ankir] telah mengingkari dua kekangan iaitu kekangan *LEKSIKAL SAMA dan TIADA KODA. Disebabkan calon [tfaykir] merupakan calon yang disalin semula maka calon tersebut telah mengingkar kekangan 
*LEKSIKAL SAMA. Manakala bagi kekangan TIADA KODA, terdapat kewujudan konsonan pada posisi maka calon [ $\mathrm{t}$ ankir] telah mengingkari kekangan tersebut.

Seterusnya, calon yang dijana dalam penilaian ini adalah [tfanke]. Leksikal "cangkir" merupakan leksikal yang berasal dari bahasa Melayu. Menurut Zaharani (2005) dalam bahasa Melayu standard segmen liquida/r/ pada posisi koda akan digugurkan. Tambahan lagi, Nur Syazwani \& Sharifah Raihan (2019) menyatakan terdapat satu lagi variasi yang berlaku iaitu, apabila konsonan likuida /r/ di akhir kata yang didahului oleh vokal tinggi seperti /u/ dan /i/ bukan sahaja digugurkan, tetapi vokal tinggi yang mendahuluinya itu mengalami perubahan kepada vokal $[\varepsilon]$ atau dalam arti kata lain berlakunya proses peleburan. Maka calon tersebut juga relevan untuk dijana dan dinilai bersama dengan dua calon sebelum ini iaitu [t $\left.\int a n k i r\right] ~ d a n$ [t faykiri]. Berdasarkan set kekangan sedia ada calon [t fanke] telah mengingkari kekangan TIADA KODA, UNIFORM-OO dan IDENT[F]-OO. Berikut merupakan tablo:

\section{1. $/ \mathrm{t}$ Jajkir $/ \longrightarrow[\mathrm{t}$ ankiri $]$}

Tablo kekangan: *LEKSIKAL SAMA $>>$ TIADA KODA $>>$ UNIFORM-OO $>>$ I DENT[F]OO $>>$ DEP-OO $>>$ MAKS-OO $>>$ ONSET $>>* V P$

\begin{tabular}{|c|c|c|c|c|c|c|c|c|}
\hline /tfankir/ & 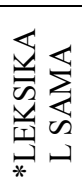 & 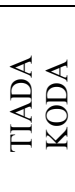 & 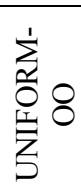 & 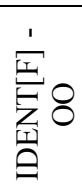 & $\begin{array}{l}8 \\
0 \\
1 \\
\text { I1 } \\
0\end{array}$ & $\begin{array}{l}8 \\
0 \\
\dot{1} \\
\text { v } \\
\Sigma \\
\Sigma\end{array}$ & $\begin{array}{l}\text { 至 } \\
\text { z } \\
0\end{array}$ & ${\underset{*}{*}}^{2}$ \\
\hline a.tfaykir & $* !$ & $* *$ & & & & & & \\
\hline b. Jaykiri & & $*$ & & $* !$ & * & & & \\
\hline c.tfanke & & $*$ & *! & $*$ & & & & \\
\hline
\end{tabular}

Berdasarkan tablo di atas, calon (b) telah berjaya menjadi calon optimal. Calon (b) telah berjaya menjadi calon optimal dengan hanya mengingkari dua kekangan yang berada pada tatatingkat ringan dalam tablo. Calon (a) telah gagal menjadi calon optimal kerana telah mengingkari dua kekangan berat dalam tablo. Hal yang sama juga berlaku pada calon (c) juga telah mengingkari dua kekangan yang berada tatatingkat ketiga dan keempat tertinggi dalam tablo. Maka set kekangan ketika ini adalah *LEKSIKAL SAMA $>>$ TIADA KODA $>>$ UNIFORM-OO $>>$ IDENT[F]-OO $>>$ DEP-OO $>>$ MAKS-OO $>>$ ONSET $>>*$ VP

\section{PERENDAHAN VOKAL}

Seterusnya, dalam penyerapan kata pinjaman bahasa Bugis menunjukkan berlakunya proses perendahan vokal. Proses perendahan vokal melibatkan vokal yang mengalami penurunan tingkat dalam rajah pengelasan vokal. Vokal tinggi /i/ akan mengalami perendahan vokal kepada vokal [e] apabila diserap masuk ke dalam bahasa Bugis. Hal ini menunjukkan bahawa terdapat sistem fonologi yang tidak membenarkan vokal tinggi hadir dalam bahasa Bugis.

Apabila kehadiran vokal tinggi tidak dibenarkan dalam bahasa Bugis, ini memberi kesan kepada output kata pinjaman bahasa Bugis. Terdapat beberapa leksikal dalam bahasa sumber mempunyai vokal tinggi dan apabila proses penyerapan berlaku, terdapat beberapa kekangan aktif yang mengakibatkan vokal tinggi bahasa sumber tidak boleh hadir dalam leksikal bahasa Bugis. Berikut merupakan data yang menunjukkan proses perendahan vokal: 
JADUAL 5. Data kata pinjaman bahasa Bugis bagi proses perendahan vokal

\begin{tabular}{ccccc}
\hline Bahasa Sumber & $\begin{array}{c}\text { Representasi } \\
\text { Fonetik }\end{array}$ & Bahasa Bugis & $\begin{array}{c}\text { Representasi } \\
\text { Fonetik }\end{array}$ & Etimologi \\
\hline bini & {$[$ biñ̃:] } & bene & {$[$ benẽ] } & Melayu \\
limau & {$[$ limãw] } & lemoh & {$[$ ləmõh] } & Melayu \\
dapur & [dapur] & dafok & [dafo?] & Melayu \\
mati & {$[$ mãti] } & mate & {$[$ mãte] } & Melayu \\
\hline
\end{tabular}

Penyerapan kata pinjaman bahasa Bugis turut melalui proses perendahan vokal. Berdasarkan data pada

JADUAL 5, perendahan vokal berlaku apabila vokal /i/ dan /u/ berada di dalam bahasa sumber. Kedua-dua leksikal tersebut direndahkan kepada vokal [e] dan [o] apabila menjadi output dalam bahasa Bugis. Sebagai contoh, leksikal /mati/ menjadi [mate] apabila diserap masuk ke dalam bahasa Bugis kerana leksikal tersebut telah melalui proses perendahan vokal. Hal ini menunjukkan vokal tinggi dalam bahasa Bugis tidak boleh hadir dalam penyerapan kata pinjaman bahasa Bugis. Berikut merupakan tablo:

Pada tahap penilaian TO, calon pertama yang dijana adalah output bahasa Bugis iaitu [mate]. Berdasarkan set kekangan sedia ada, calon [mate] telah mengingkari kekangan IDENT[F]-OO. Oleh kerana berlakunya perubahan fitur segmen /i/ ke [e] dalam penyerapan kata pinjaman bahasa Bugis maka calon tersebut telah mengingkari kekangan IDENT[F]-OO. Calon kedua yang dijana dalam penilaian ini adalah output bagi bahasa sumber iaitu /mati/. Calon tersebut telah mengingkari kekangan *LEKSIKAL SAMA.

Seterusnya, calon yang dijana dalam penilaian ini ialah [mati:]. Walaupun etimologi bagi perkataan 'mati' dari bahasa Melayu, namun fenomena pemanjangan vokal turut berlaku dalam bahasa Melayu. Menurut Norfazila \& Rahim (2014) dalam bahasa Melayu, terdapat dua fenomena fonologi yang melibatkan segmen vokal, iaitu proses pemanjangan dan proses penyisipan vokal. Namun, kedua-dua proses ini tidak mendapat pertimbangan yang saksama dalam konteks pengkajian fonologi bahasa Melayu. Oleh itu, dalam penilaian kali ini calon yang mempunyai fenomena pemanjangan vokal dijana untuk melihat sama ada fenomena pemanjangan vokal ini turut diserap ke dalam bahasa Bugis. Berdasarkan calon [mati:] ini, dua kekangan yang telah diingkari iaitu kekangan *VP dan DEP-OO. Berikut merupakan tablo:

\section{1. $/ \mathrm{mati} / \longrightarrow[$ mate $]$}

Tablo kekangan: *LEKSIKAL SAMA $>>*$ VP $>>$ DEP-OO $>>$ IDENT[F]-OO $>>$ MAKS-OO $>$ ONSET $>>$ UNIFORM-OO $>>$ TIADA KODA

\begin{tabular}{|c|c|c|c|c|c|c|c|c|}
\hline /mãti/ & 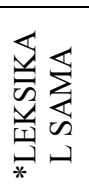 & $\overbrace{*}^{P}$ & $\begin{array}{l}8 \\
0 \\
i \\
\text { ज्ञ } \\
\text { 1 }\end{array}$ & 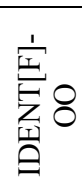 & $\begin{array}{l}8 \\
0 \\
1 \\
\vdots \\
y \\
\Sigma\end{array}$ & 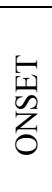 & 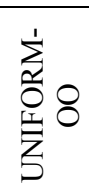 & 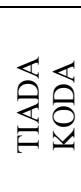 \\
\hline a.mãti & $* !$ & & & & & & & \\
\hline b.mãte & & & & $* !$ & & & & \\
\hline
\end{tabular}




\begin{tabular}{|l|l|l|l|l|l|l|l|l|} 
c.mãti: & & $* !$ & $*$ & & & & & \\
\hline
\end{tabular}

Berdasarkan tablo di atas, calon (a) telah tewas untuk menjadi calon optimal kerana calon (a) yang merupakan kata pinjaman penyerapan penuh telah mengingkari kekangan yang paling berat dalam tablo iaitu kekangan *LEKSIKAL SAMA. Manakala calon (c) juga turut tewas untuk menjadi calon optimal kerana telah mengingkari dua kekangan yang berada pada posisi kedua dan ketiga dalam tablo. Oleh itu, hanya tinggal calon (b) sahaja yang merupakan calon yang optimal dalam penilaian ini. Calon (b) hanya mengingkari kekangan IDENT[F]OO sahaja dan ini membuatkan calon (b) telah berjaya menjadi calon pemenang. Berdasarkan penilaian ini set kekangan ketika ini adalah *LEKSIKAL SAMA $>>*$ VP $>>$ IDENT[F]-OO $>>$ DEP-OO $>>$ MAKS-OO $>>$ ONSET $>>$ UNIFORM-OO $>>$ TIADA KODA.

\section{PENGGANTIAN NASAL}

Berbeza dengan proses penggantian sebelum ini, data juga menunjukkan terdapat proses penggantian nasal berlaku dalam penyerapan kata pinjaman. Proses penggantian ini berlaku apabila sesuatu segmen digantikan dengan konsonan nasal (Sharifah Raihan, 2013 \& 2015). Berdasarkan data pada JADUAL 6 apabila konsonan nasal $/ \mathrm{n} / \mathrm{dan} / \mathrm{m} /$ berada pada posisi koda akhir suku kata, segmen tersebut akan digantikan dengan konsonan nasal velar [y]. Berikut merupakan data:

JADUAL 6. Data kata pinjaman bahasa Bugis bagi proses penggantian nasal

\begin{tabular}{|c|c|c|c|c|}
\hline Bahasa Sumber & $\begin{array}{l}\text { Representasi } \\
\text { Fonetik }\end{array}$ & Bahasa Bugis & $\begin{array}{l}\text { Representasi } \\
\text { Fonetik }\end{array}$ & Etimologi \\
\hline jam & 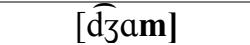 & jang & 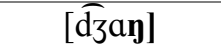 & Melayu \\
\hline telephone & [tclıfər $]$ & talifong & [talifon] & Inggeris \\
\hline televition & [teli vizon] & talibiseng & [talibisen] & Inggeris \\
\hline minum & [mĩnũm] & minung & [mĩnũy] & Melayu \\
\hline rambutan & [rambutan] & rambutang & [rambutan] & Melayu \\
\hline jamban & [czamban] & jambang & [camban] & Melayu \\
\hline microphone & [mã.k.kor.forn] & mikrofong & [mãjkrofon] & Inggeris \\
\hline daun & [dawun] & dawung & [daun] & Melayu \\
\hline penimbang & [pənĩmban] & patimbang & [patimban] & Melayu \\
\hline
\end{tabular}




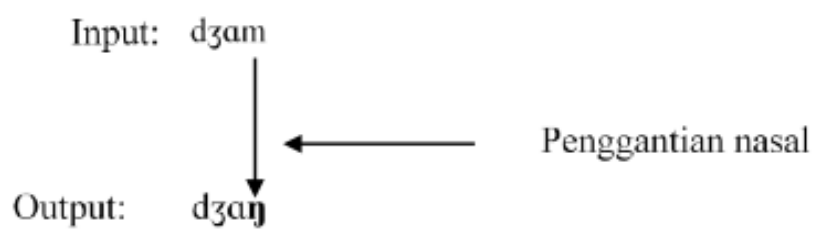

RAJAH 4. Perubahan struktur akibat proses penggantian nasal

Berdasarkan

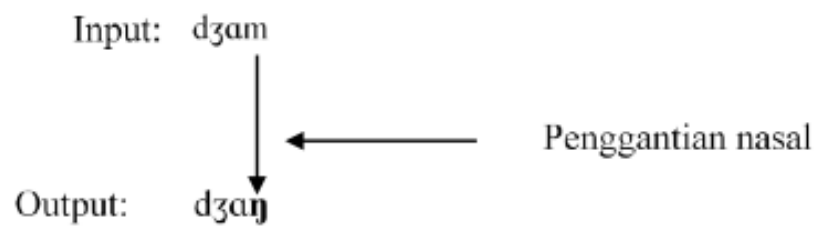

RAJAH 4 kata pinjaman / đ̧am/ yang mempunyai konsonan /m/ pada posisi koda di akhir suku kata yang telah mengalami proses penggantian di mana segmen $/ \mathrm{m} /$ telah digantikan kepada [y] dalam output bahasa Bugis. Maka untuk penilaian TO bagi proses ini, calon pertama yang dijana pada output bahasa Bugis iaitu [dzan]. Berdasarkan set kekangan sedia ada, calon tersebut telah mengingkari kekangan IDENT[F]-OO dan TIADA KODA. Penjanaan calon

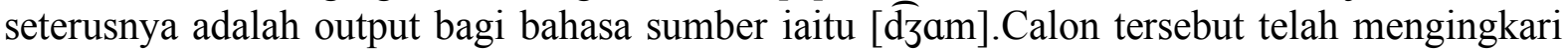
dua set kekangan sedia ada iaitu, *LEKSIKAL SAMA dan TIADA KODA. Akhir sekali, calon yang dijana dalam penilaian ini ialah [dza:]. Berdasarkan calon tersebut, kekangan yang telah diingkari adalah *VP , MAKS-OO dan DEP-OO. Berikut merupakan tablo:

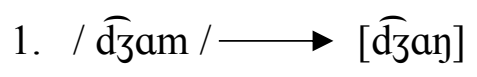

Tablo kekangan: *LKSIKAL SAMA $>>*$ VP $>>$ MAKS-OO $>>$ IDENT[F]-OO $>>$ TIADA KODA $>>$ DEP-OO $>>$ ONSET $>>$ UNIFORM-OO

\begin{tabular}{|c|c|c|c|c|c|c|c|c|}
\hline /dzam/ & 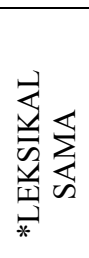 & $\underset{*}{*}$ & $\begin{array}{l}8 \\
0 \\
1 \\
\\
\vdots \\
\Sigma\end{array}$ & 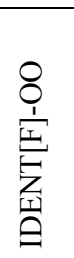 & 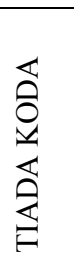 & $\begin{array}{l}8 \\
8 \\
1 \\
1 \\
1 \\
0\end{array}$ & 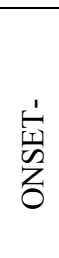 & 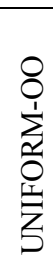 \\
\hline a. dzan & & & & *! & $*$ & & & \\
\hline b. dzam & $* !$ & & & & * & & & \\
\hline c. dza: & & $* !$ & $*$ & & & * & & \\
\hline
\end{tabular}

Tablo di atas menunjukkan calon (a) telah berjaya diterbitkan sebagai calon optimal untuk penilaian proses penggantian nasal ini. Calon (b) telah tewas menjadi calon optimal kerana kekangan *LEKSIKAL SAMA yang telah diingkari berada pada tatatingkat yang paling berat di dalam tablo. Sebab utama calon (b) gagal menjadi calon optimal kerana, calon (b) merupakan kata pinjaman penyerapan penuh. Oleh kerana, kekangan *LEKSIKAL SAMA tidak membenarkan dua leksikal yang sama wujud dalam leksikon, maka calon (b) tewas. Manakala bagi calon (c) telah tewas dengan mengingkari kekangan *VP yang berada pada 
posisi kedua hierarki kekangan tablo. Oleh itu, hanya tinggal calon (a) sahaja yang layak untuk menjadi calon optimal. Oleh itu, set kekangan pada peringkat ini adalah *LEKSIKAL SAMA $>>$ *VP $>>$ MAKS-OO $>>$ IDENT[F]-OO $>>$ TIADA KODA $>>$ DEP-OO $>>$ ONSET $>>$ UNIFORM-OO

\section{HENTIAN GLOTIS}

Jika dilihat pada data di jadual sebelum ini, terdapat data yang menunjukkan berlaku dua proses fonologi dalam satu leksikal. Selain daripada proses yang telah dinyatakan sebelum ini, data juga menunjukkan berlakunya proses hentian glotis. Proses hentian glotis berlaku pada suku kata terakhir di posisi koda. Hentian glotis merupakan bunyi konsonan yang terhasil dan dilepaskan pada bahagian glotis. Tambahan lagi, secara umumnya hentian glotis merujuk kepada hentian yang dibuat di bahagian glotal dan kekal dalam penutupan lipatan vokal. Berdasarkan data, proses hentian glotis berlaku dengan dua cara. Cara yang pertama adalah dengan berlaku penyisipan glotis dan cara kedua berlakunya penggantian glotis. Berikut merupakan data yang dimaksudkan:

JADUAL 7. Data kata pinjaman bahasa Bugis bagi proses penggantian glotis

\begin{tabular}{ccccc}
\hline Bahasa Sumber & $\begin{array}{c}\text { Representasi } \\
\text { Fonetik }\end{array}$ & Bahasa Bugis & $\begin{array}{c}\text { Representasi } \\
\text { Fonetik }\end{array}$ & Etimologi \\
\hline dapur & [dapur] & dafok & [dafo?] & Melayu \\
angkat & [ankat] & akak & [aka?] & Melayu \\
salamat & {$[$ salamãt] } & salamak & {$[$ salamã?] } & Arab \\
\hline
\end{tabular}

JADUAL 8. Data kata pinjaman bahasa Bugis bagi proses penyisipan glotis

\begin{tabular}{|c|c|c|c|c|}
\hline Bahasa Sumber & $\begin{array}{c}\text { Representasi } \\
\text { Fonetik }\end{array}$ & Bahasa Bugis & $\begin{array}{c}\text { Representasi } \\
\text { Fonetik }\end{array}$ & Etimologi \\
\hline joget & [d]oget] & majogek & [mad̄zoge?] & Melayu \\
\hline bus & [bas] & basek & [base?] & Inggeris \\
\hline bicycle & ['baisıkl] & basikarak & [basikara?] & Perancis \\
\hline arnab & [arnap] & arnabek & [arnabe?] & Arab \\
\hline manggis & [mãygis] & manggisik & [mãygisi?] & Melayu \\
\hline anggur & [aygur] & anggorok & [aygoro?] & Parsi \\
\hline siku & [siku] & sikkuk & [si?ku?] & Melayu \\
\hline sudu & [sudu] & suruk & [suru?] & Melayu \\
\hline senduk & [səndu?] & sanderuk & [sandəru?] & Melayu \\
\hline
\end{tabular}

Berdasarkan data yang terdapat pada JADUAL 7 dan JADUAL 8 kewujudan hentian glotis bagi kedua-dua proses mempunyai peranannya tersendiri. Berdasarkan data fungsi hentian glotis adalah sebagai penutup suku kata. Hanya terdapat beberapa sahaja konsonan yang dibenarkan hadir pada posisi koda dan salah satunya adalah konsonan hentian glotis. JADUAL 8 memperlihatkan konsonan $/ \mathrm{r} /$ dan $/ \mathrm{t} / \mathrm{yang}$ berada posisi koda telah digantikan kepada hentian glotis. Kedua-dua konsonan tersebut merupakan konsonan alveolar. Berbeza dengan penggantian nasal, penggantian tersebut hanya melibatkan konsonan nasal dan digantikan dengan konsonan yang berhomorganik, iaitu $/ \mathrm{y} /$.

Pada waktu yang sama, hentian glotis ini juga disisip pada posisi koda bertujuan untuk memberat suku kata. Berdasarkan JADUAL 8 strategi yang digunakan dalam penyerapan kata pinjaman ini adalah apabila leksikal kata pinjaman yang mempunyai konsonan yang tidak dibenarkan hadir pada posisi tidak akan digugurkan, tetapi akan hadir satu vokal yang sama ketinggian atau lebih tinggi wujud pada posisi konsonan tersebut. Sebagai contoh, leksikal /bas/, konsonan /s/ tidak dibenarkan hadir pada posisi koda maka satu vokal akan hadir iaitu 
vokal /e/ yang merupakan vokal tengah. Vokal /e/ merupakan vokal separuh tinggi dan vokal tersebut lebih tinggi berbanding dengan vokal yang hadir sebelum ini. Maka pada tahap ini, peranan hentian glotis sebagai penutup suku kata hadir.

Strategi proses hentian glotis telah diperjelaskan dan didapati bahawa berlakunya dua proses dalam hentian glotis proses yang pertama ialah penggantian glotis, di mana segmen di dalam leksikal digantikan dengan konsonan hentian glotis dan proses yang kedua adalah penyisipan hentian glotis. Proses penggantian hentian glotis berlaku apabila satu segmen digantikan dengan konsonan hentian glotis. Berikut merupakan skema penyerapan kata pinjaman bagi proses penggantian hentian glotis:

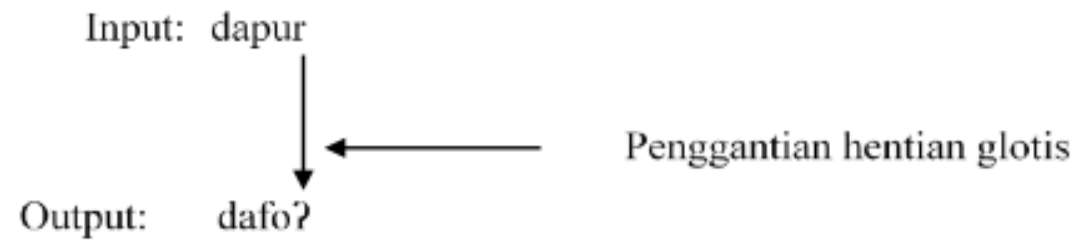

RAJAH 5. Perubahan struktur akibat proses penggantian hentian glotis

Manakala bagi proses kedua iaitu penyisipan hentian glotis, memperlihatkan konsonan hentian glotis telah disisip masuk pada posisi koda. Terdapat proses penyisipan hentian glotis hadir selepas proses epentesis dan terdapat juga penyisipan konsonan hentian hadir sebagai pemberat suku kata. Berikut merupakan skema penyerapan kata pinjaman bagi proses penyisipan hentian glotis:

Penilaian TO bagi hentian glotis ini akan dimulakan dengan proses penggantian glotis. Berdasarkan Error! Reference source not found.calon pertama yang dijana dalam penilaian ini adalah [dafo?]. Berdasarkan calon tersebut, kekangan yang telah diingkari dalam penilaian ini adalah IDENT[F]-OO dan TIADA KODA. Calon seterusnya yang turut bertanding dalam penilaian ini adalah [dapur]. Calon tersebut merupakan output kepada bahasa sumber dan berdasarkan penilaian terhadap calon tersebut, kekangan yang telah diingkari adalah *LEKSIKAL SAMA dan TIADA KODA. Akhir sekali, calon yang turut dijana adalah [dapu:]. Calon tersebut telah mengingkari tiga kekangan sedia ada iaitu *VP, MAKS-OO dan DEPOO. Berikut merupakan tablo:

\section{1. / dapur $\longrightarrow[$ dafo?]}

Tablo kekangan: *LEKSIKAL SAMA $>>$ VP $>>$ MAKS-OO $>>$ IDENT[F]-OO $>>$ TIADA KODA $>>$ DEP-OO $>>$ ONSET $>>$ UNIFORM-OO

\begin{tabular}{|c|c|c|c|c|c|c|c|c|}
\hline / dapur/ & 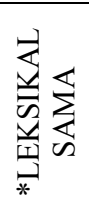 & ${\underset{*}{*}}^{2}$ & 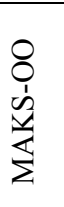 & $\begin{array}{l}\text { 㹂。 } \\
\text { 空 }\end{array}$ & 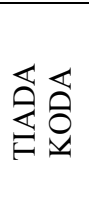 & $\begin{array}{l}8 \\
0 \\
\vdots \\
1 \\
0 \\
0\end{array}$ & $\begin{array}{l}\sqrt[y]{5} \\
\text { 荡 } \\
0\end{array}$ & 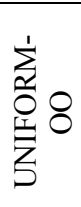 \\
\hline a. dafo? & & & & $* !$ & $*$ & & & \\
\hline b. dapur & $* !$ & & & & $*$ & & & \\
\hline c. dapu: & & $* !$ & $*$ & & & $*$ & & \\
\hline
\end{tabular}


Berdasarkan tablo di atas, calon (a) telah berjaya menjadi calon optimal. Oleh kerana calon (b) merupakan salinan semula daripada input bahasa sumber maka calon tersebut telah tewas dengan mengingkari kekangan di tatatingkat paling berat di dalam tablo. Calon (c) turut tewas dalam penilaian dengan mengingkari kekangan yang berada pada tatatingkat kedua. Oleh sebab kedua-dua calon tersebut tewas maka calon (a) telah menjadi calon optimal. Maka pada peringkat ini set kekangan yang ada adalah *LEKSIKALSAMA $>>$ *VP $>>$ MAKS-OO $>>$ IDENT[F]-OO $>>$ TIADAKODA $>>$ DEP-OO $>>$ ONSET $>>$ UNIFORM-OO.

Seterusnya, penilaian akan dilakukan pada data proses penyisipan glotis. Calon pertama yang dijana dalam penilaian ini adalah [sikku?] yang merupakan output bahasa Bugis. Calon tersebut telah mengingkari dua kekangan dalam penilaian ini iaitu TIADA KODA dan DEP-OO. Calon seterusnya adalah output bagi bahasa sumber iaitu [siku]. Calon tersebut telah mengingkari kekangan *LEKSIKAL SAMA. Calon yang terakhir yang dijana dalam penilaian ini adalah [siku:]. Berdasarkan penilaian kekangan sedia ada, calon tersebut telah mengingkari kekangan *VP dan DEP-OO. Berikut merupakan tablo:

\section{2. $/$ siku $/ \longrightarrow[$ sirku? $]$}

Tablo kekangan: *LEKSIKAL SAMA $>>*$ VP $>>$ IDENT[F]-OO $>>$ TIADA KODA $>>$ DEPOO $>>$ MAKS-OO $>>$ ONSET $>>$ UNIFORM-OO

\begin{tabular}{|c|c|c|c|c|c|c|c|c|}
\hline /siku/ & 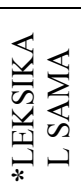 & $\underset{*}{7}$ & 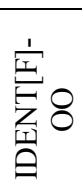 & 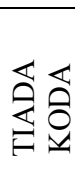 & $\begin{array}{l}8 \\
0 \\
i \\
\stackrel{1}{11} \\
0\end{array}$ & \begin{tabular}{l}
8 \\
0 \\
$\dot{n}$ \\
\multirow{2}{\Sigma}{} \\
$\Sigma$
\end{tabular} & 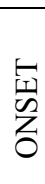 & 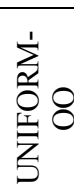 \\
\hline a.si?ku? & & & & $* * !$ & $* *$ & & & \\
\hline b.siku & $* !$ & & & & & & & \\
\hline c.siku: & & $* !$ & & & $*$ & & & \\
\hline
\end{tabular}

Berdasarkan tablo di atas, calon (a) telah berjaya menjadi calon optimal dalam penilaian ini. Calon (a) telah mengingkari kekangan TIADA KODA sebanyak dua kali kerana jika dirujuk pada tablo terdapat dua kewujudan koda iaitu pada suku kata pertama dan kedua. Pada waktu yang sama, kewujudan koda disebabkan berlakunya penyisipan hentian glotis, maka kekangan DEP-OO juga telah diingkari sebanyak dua kali. Calon (b) telah tewas pada awal penilaian ini kerana calon tersebut telah mengingkari kekangan yang berada pada tatatingkat paling berat di dalam tablo diikuti calon (c) yang telah tewas selepasnya dengan mengingkari kekangan yang berada pada tatatingkat kedua. Oleh itu, set kekangan pada peringkat ini adalah *LEKSIKAL SAMA $>>$ *VP $>>$ IDENT[F]-OO $>>$ TIADA KODA $>>$ DEP-OO $>>$ MAKSOO $>>$ ONSET $>>$ UNIFORM-OO.

\section{GEMINASI}

Geminasi merupakan proses satu konsonan menjadi dua konsonan yang sama secara bergugus. Tambahan lagi, menurut Kubozono, Ito dan Mester (2009), proses geminasi ini tidak akan muncul jika tiada sebarang dorongan. Berdasarkan data, kemunculan proses geminasi dalam penyerapan kata pinjaman dalam bahasa Bugis adalah bertujuan untuk membina satu suku kata berat-ringan (heavy-light (HL)) atau berat-berat (heavy-heavy $(H-H)$ ) pada posisi akhir kata. Berikut merupakan data: 


\begin{tabular}{ccccc}
\hline Bahasa Sumber & $\begin{array}{c}\text { Representasi } \\
\text { Foentik }\end{array}$ & Bahasa Bugis & $\begin{array}{c}\text { Representasi } \\
\text { Fonetik }\end{array}$ & Etimologi \\
\hline telur & {$[$ telo] } & tello & {$[$ təllo] } & Melayu \\
besi & {$[$ bãssi] } & bassi & {$[$ bassi] } & Melayu \\
rebah & {$[$ robah] } & rebba & {$[$ rəbba] } & Melayu \\
menantu & {$[$ mãnãntu] } & manettu & {$[$ manãttu] } & Melayu \\
sabar & {$[$ sabar] } & sabbarak & {$[$ sabbara?] } & Arab \\
siku & {$[$ siku] } & sikku & {$[$ sikku?] } & Melayu \\
sentul & {$[$ səntul] } & settung & {$[$ səttur] } & Melayu \\
gula & {$[$ gula] } & golla & [golla] & Sanskrit \\
kapal & {$[$ kapal] } & kappala & {$[$ kappala] } & Tamil \\
\hline
\end{tabular}

Berdasarkan jadual di atas, kesemua data merupakan suku kata HL kecuali bagi leksikal [səttuy] yang merupakan suku kata $\mathrm{HH}$. Antara konsonan yang dapat dilihat mengalami proses geminasi adalah $/ 1 /, / \mathrm{s} /, / \mathrm{b} /, / \mathrm{t} /, / \mathrm{k} /$, dan $/ \mathrm{p} /$ dan berikut merupakan struktur proses geminasi dalam penyerapan kata pinjaman bahasa Bugis.

calon pertama yang dijana dalam penilaian ini adalah output [golla]. Berdasarkan set kekangan sedia ada, calon tersebut telah mengingkari kekangan IDENT[F]-OO, TIADA KODA, dan DEP-OO. Pada waktu yang sama, calon tersebut telah mengingkari kekangan iaitu *GEM. Kekangan *GEM merupakan kekangan di bawah keluarga kebertandaan yang tidak membenarkan konsonan panjang atau geminasi berlaku. Calon seterusnya yang dijana dalam penilaian ini ialah [gula] yang merupakan output bahasa sumber dan calon tersebut telah mengingkari kekangan *LEKSIKAL SAMA. Calon ketiga yang dijana adalah [gula:] dan calon tersebut telah mengingkari kekangan *VP dan DEP-OO.

Akhir sekali, calon yang dijana dalam penilaian adalah [gulə]. Dalam penilaian ini, calon tersebut telah mengingkari kekangan IDENT[F]-OO kerana vokal /a/ yang berada pada posisi koda telah diubah kepada [ə]. Satu lagi penambahan kekangan yang telah diingkari oleh calon [gulə] iaitu *SCHWA. Kekangan *SCHWA merupakan kekangan yang tidak membenarkan kehadiran vokal schwa /ə/ berada dalam leksikal. Oleh kerana berlakunya reduksi vokal /a/ pada calon [gulə].maka calon tersebut telah mengingkari kekangan tersebut. Berikut merupakan tablo:

9) *SCHWA

tidak membenarkan kehadiran vokal schwa /a/

10) * GEM

tiada konsonan panjang

1. / gula $/ \longrightarrow$ [golla]

Tablo kekangan: *LEKSIKALSAMA $>$ *VP $>$ *SCHWA $>$ IDENT-OO $>>$ TIADAKODA $>>$ DEP-OO $>>*$ GEM $>>$ MAKS-OO $>>$ ONSET $>>$ UNIFORM-OO

\begin{tabular}{|c|c|c|c|c|c|c|c|c|c|c|}
\hline /gula/ & 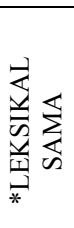 & $F_{*}^{2}$ & 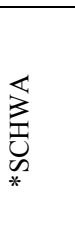 & 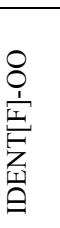 & 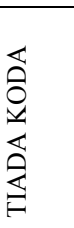 & 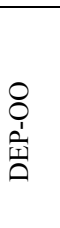 & $\sum_{\underset{\text { }}{*}}$ & 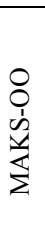 & $\begin{array}{l}\hat{y} \\
\text { 点 } \\
\text { z }\end{array}$ & 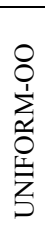 \\
\hline a.gula & $* !$ & & & & & & & & & \\
\hline b.gula: & & *! & & & & * & & & & \\
\hline c.golla & & & & * & *! & * & * & & & \\
\hline d.gulə & & & $* !$ & $*$ & & & & & & \\
\hline
\end{tabular}


Berdasarkan tablo di atas calon (c) telah berjaya menjadi calon optimal dalam penilaian ini. Calon (a) merupakan calon yang pertama telah terkeluar dalam penilaian ini kerana telah mengingkari kekangan yang berada pada tatatingkat paling berat sekali. Diikuti calon (b) yang telah tewas dengan mengingkari kekangan yang berada pada tatatingkat kedua. Seterusnya, calon yang tewas selepas calon (b) adalah calon (d) yang telah mengingkari kekangan pada tatatingkat ketiga. Oleh itu, dalam penilaian ini calon (c) telah muncul sebagai pemenang. Maka set kekangan yang terakhir ialah *LEKSIKALSAMA $>>$ *VP $>>*$ SCHWA $>>$ IDENT[F]-OO $>>$ TIADAKODA $>>$ DEP-OO $>>$ *GEM $>>$ MAKS-OO $>>$ ONSET $>>$ UNIFORM-OO

\section{KESIMPULAN}

Kajian ini telah dijalankan untuk mengenal pasti strategi adaptasi kata pinjaman dalam bahasa Bugis serta menjelaskan proses adaptasi yang terlibat menggunakan TO dan Kor-OO. Hasil kajian ini mendapati bahawa, sebanyak lapan proses adaptasi yang berlaku dalam penyerapan kata pinjaman bahasa Bugis iaitu peleburan, pengguguran, penggantian segmen, epentensis, perendahan vokal, penggantian nasal, hentian glotis, dan geminasi. Hal ini menunjukkan bahawa terdapat beberapa sistem fonologi dari kata pinjaman tidak sesuai untuk diserap sepenuhnya ke dalam bahasa Bugis. Buktinya, berdasarkan analisis set tatatingkat kekangan menggunakan Kor-OO kekangan yang perlu dipatuhi dalam penyerapan kata pinjaman dalam bahasa Bugis ialah *LEKSIKALSAMA $>$ *VP $>>$ *SCHWA $>>$ IDENT[F]OO $>>$ TIADAKODA $>>$ DEP-OO $>>*$ GEM $>>$ MAKS-OO $>>$ ONSET $>>$ UNIFORM-OO.

Secara rumusannya, hasil kajian ini telah menjadi satu nilai tambah kepada kajian masyarakat Bugis dari sudut linguistik. Kajian ini telah membuktikan bahawa masyarakat Bugis sudah mula berasimilasi dengan masyarakat setempat dengan menyerap masuk beberapa leksikal pinjaman bagi memastikan komunikasi sehari-hari mereka dapat difahami. Hasil kajian ini telah berjaya mengesan lapan proses fonologi yang digunakan dalam adaptasi kata pinjaman bahasa Bugis. Pada waktu yang sama, kajian ini juga telah berjaya menunjukkan kemampuan Kor-OO dalam membincangkan isu kata pinjaman yang melibat dua bahasa tanpa mengingkari konsep penting dalam TO iaitu keselarian (parallelism).

\section{PENGHARGAAN}

Kajian ini telah dibiayai oleh Universiti Kebangsaan Malaysia di bawah Geran Universiti Penyelidikan (GUP-2018-003).

\section{RUJUKAN}

Alahmari, Musa. (2021). Prosodic Adaptation Of Superheavy Syllables In Arabic Loanwords In Turkish: An Optimality-Theoretic Analysis. Journal of King Abdulaziz UniversityArts and Humanities 29(1), 581-596.

Andi Adijah, Rosman Md Yusoff, Mohd Koharud Moh Balwi \& Tariq Ahmad. (2017). Reconstruction of ethnic identity among bugis community in Pontian Johor. Journal of Management Info, 4(2), 5-8.

Aznur Aisyah, A., \& Zaharani, A. (2017). An optimality analysis of Malay loanwords in Japanese. Akademika, 87(1), 303-314. 
Benua, L. (1997). Transderivational identity: phonological relations between words (Doctoral dissertation).

Brown, K. \& Miller, J. (2013). The Cambridge dictionary of linguistics. UK: Cambridge Universiti Press.

Dedy Suhery, Mohd Hamid Raza, Happy Sri Rezeki Purba, Khairunnisah. (2019). An Optimality theory account of English loanwords in Pilibhit Hindi-Urdu (Uttar Pradesh) India. International Journal of Engineering and Advanced Technology (IJEAT), 8(5C), 2249-8958.

Fitrah, Y., \& Afria, R. (2017). Kekerabatan bahasa-bahasa etnis Melayu, Batak, Sunda, Bugis, dan Jawa Di Provinsi Jambi: sebuah kajian linguistik historis komparatif. Titian: Jurnal Ilmu Humaniora, 1(2), 204-218.

Guo, H. L. Y. (1999). Mandarin loanword phonology and optimality theory: Evidence from transliterated American state names and typhoon names. In Proceedings of the 13th Pacific Asia Conference on Language, Information and Computation (pp. 191-202).

Hasmawati Hasbullah. (2014). Pengenalan prefiks yang tidak dapat dipisah (untrennbare prafixe) dan prefiks yang dapat-tidak dapat dipisah (trennbare-untrennbare prafixe] pada pengajaran bahasajermandi indonesia. Prosiding Koloqium Internasional Khazanah Pendidikan di Alam Melayu.

Holmes, J., \& Wilson, N. (2017). An Introduction to Sociolinguistics (5th ed.). Routledge. https://doi.org/10.4324/9781315728438

Jacobs, H., Gussenhoven, C., 2000. Loan phonology: perception, salience, the lexicon, and OT. In: Dekkers, J., van der Leeuw, F., van der Weijer, J. (Eds.), Optimality Theory: Phonology, Syntax and Acquisition. Oxford University Press, 193-210.

Johar Amir. (2011). Sapaan dalam bahasa Bugis dialek sidrap. Jurnal Ilmiah Masyarakat Linguistik Indonesia, Februari 2011, 69 - 83.

Jumiati, W. (2016). Makna Prefiks bahasa Bugis kelurahan Puulemo kecamatan Poleang Timur Kabupaten Bombana. Jurnal Humanika, 3(16).

Kobozono Haruo, Junko Ito, and Armin Mester. (2009). Consonant Gemination in Japanese Loanword Phonology. In: The Linguistic Society of Korea. ed. Current Issues in Unity and Diversity of Languages. Collection of Papers Selected from the 18th International Congress of Linguists [CIL 18]. Dongam Publishing Co., Republic of Korea. 953-973..

Leeuw, F., van der Weijer, J. (Eds.), Optimality Theory: Phonology, Syntax and Acquisition. Oxford University Press,

Macknight, C. C. (Ed.). (2012). Bugis and Makasar: two short grammars. Karuda Press.

Makmur Harun, Buchari Katutu \& Siti Rachmawati Yahya. (2014). Diaspora Bugis di Sumatra menyelusuri seni dan Budaya Bugis di Provonsi Jambi. Kertas kerja dibentangkan di Perisdangan Kembara Warisan Bugis At Melaka. Fakulti Bahasa dan Komunikasi Universiti Pendidikan Sultan Idris (UPSI).

Mansur Tanha \& Asmiaty Ahmad. (2021). Siri' dalam elong masyarakat Bugis di daerah Tawau, Sabah. Jurnal Pengajian Melayu (JOMAS), 32(1), 29-48.

Mansur Tanha, Asmiaty Ahmad \& Lokman, Abdul Samad. (2019). Pemmali dalam masyarakat Bugis di pantai timur Sabah. Jurnal Komunikasi Borneo (JKoB), 7(1), 29-39.

McCarthy, J. J. \& Prince, A. S. (1993). Prosodic morphology I : constraint interaction and satisfaction. Massachusetts: MIT Press.

McCarthy, J. J. \& Prince, A. S. (1995). Faithfulness and reduplicative identity. University of Massachusetts Occasional Papers in Linguistics UMOP 18: 249-38.

Nor Hazila Mat Lazim \& Sharifah Raihan Syed Jaafar. (2018). Delikuidasi kata pinjaman Arab dalam dialek Kelantan. GEMA Online Journal of Language Studies, 18(4), 236-250. 
Norhayati Abdul Rahman. (2016). Sejarah hubungan masyarakat Melayu dan Bugis sebagai asas pembinaan naratif dalam novel sasterawan negara arena wati. MANU: Jurnal Pusat Penataran Ilmu dan Bahasa (PPIB).

Nur Syazwani, S., \& Sharifah Raihan Syed Jaafar. (2019). Perilaku fonologi konsonan di akhir kata dialek Petani Sik [The phonological behaviour of word-final consonants in the Petani Sik dialect]. Journal of Nusantara Studies (JONUS), 4(1), 316-343.

Oktaviani, Y., Syahrani, A., \& Jupitasari, M. (2021). Tuturan keinterogatifan bahasa bugis wajo'isolek di Padang Tikar: kajian fonetik akustik. Jurnal Elektronik Wacana Etnik, 10(1), 45-57.

Paduai, H. A. (2013). Inovasi fonologis dan variasi leksikal dalam bahasa Bugis dialek Sinjai. PAROLE: Journal of Linguistics and Education, 3(2 Okt), 29-42.

pp. 193-210Jasni Ahmad. (2016). Bugis di Kedah 1600-1800: suatu tinjauan awal. Conference Proceedings of the ICECRS, 1(1), 25-27 Oktober, Universiti Utara Malaysia.

Rahilah, O., Bungo, N., Nordin, H., \& Bidin, A. (2012). Early history of Bugis settlement in Selangor. Pertanika Journal of Social Sciences \& Humanities, 20(3), 917-930.

Ridhwan, R. (2019). Kepercayaan masyarakat Bugis PRA Islam. Ekspose: Jurnal Penelitian Hukum dan Pendidikan, 17(1), 481-498.

Roach, P. (2000). English phonetics and phonology. Cambridge University.

Rosmiza Mohd Zainol \& Sharifah Raihan Syed Jaafar. (2021). Adat dan amalan masyarakat Bugis di Pontian, Johor dalam aktiviti perikanan. Jurnal Dunia Perniagaan, 3(1), 1-8.

Rusdiansyah, R., \& Retty, I. (2018). Language attitudes of buginese speakers in bandung. ideas: Journal on English Language Teaching and Learning, Linguistics and Literature, 6(2), 49-61

Sharifah Raihan Syed Jaafar. (2013). Nasal Substitution in Sarawak Malay Dialect. Asian Social Science Journal .Vol. 9(4), 91-99.

Sharifah Raihan Syed Jaafar. (2015). Nasality and Voicing in non-standard dialects of Malay. Issue 15. Dialectologia Revista Electronica Journal, 137-156.

Sua, A. T., Anshari, A., \& Maman, M. (2020). Bentuk, fungsi, dan nilai ungkapan Bugis masyarakat Bone. Edumaspul. Jurnal Pendidikan, 4(1), 288-295.

Thamaraselvi Krishnasamy \& Sharifah Raihan Syed Jaafar. (2018). Fonologi kata pinjaman Tamil dalam bahasa Melayu berdasarkan teori Optimaliti. Jurnal Bahasa 18(2), 343362.

Trask, R. L. (2000). The dictionary of historical and comparative linguistics. Psychology Press.

Wekke, I. S., Ladiqi, S., \& Bustami, R. (2019). Bugis and Madura migration in Nusantara: religiosity, harmony, and identity from eastern Indonesia. Ulul Albab, 20(1), 1-24.

Yatim, A. H. M., Ahmad, M. H., \& Rahim, M. S. A. (2020). Perburuhan dan masyarakat Bugis di Sabah: analisis kajian terdahulu. E-Bangi, 17(6), 193-202.

Zibin, A. (2019). A phonological analysis of English loanwords inflected with Arabic morphemes in Urban Jordanian spoken Arabic. SAGE Open, 9(2), 1-13. https://doi.org/10.1177/2158244019841927

Zurina Abdullah \& Muhammad Abdul Jalal Abdullah. (2019). Pengikisan amalan adat perkahwinan masyarakat bugis: Kajian kes di kampung Permatang Duku, Pontian, Johor. Jurnal Melayu, 18(2). 269-280.

\section{PENULIS}

Muhammad Firdaus bin Mohd Sah ialah pelajar Ph.D di Pusat Kajian Bahasa dan Linguistik, Fakulti Sains Sosial dan Kemanusiaan, UKM. dausfy95@gmail.com 
Sharifah Raihan binti Syed Jaafar (Ph.D) ialah pensyarah kanan di Pusat Kajian Bahasa dan Linguistik, Fakulti Sains Sosial dan Kemanusiaan, UKM. Bidang pengkhususan beliau ialah teoretikal fonologi dan morfologi'. 